Florida International University FIU Digital Commons

$11-9-2012$

\title{
The Effectiveness of Outdoor Education on Environmental Learning, Appreciation, and Activism
}

Jessica Okaty

Florida International University, jessicaokaty@me.com

DOI: $10.25148 /$ etd.FI12120518

Follow this and additional works at: https://digitalcommons.fiu.edu/etd

\section{Recommended Citation}

Okaty, Jessica, "The Effectiveness of Outdoor Education on Environmental Learning, Appreciation, and Activism" (2012). FIU

Electronic Theses and Dissertations. 791.

https://digitalcommons.fiu.edu/etd/791

This work is brought to you for free and open access by the University Graduate School at FIU Digital Commons. It has been accepted for inclusion in FIU Electronic Theses and Dissertations by an authorized administrator of FIU Digital Commons. For more information, please contact dcc@fiu.edu. 


\section{FLORIDA INTERNATIONAL UNIVERSITY}

Miami, FL

\section{THE EFFECTIVENESS OF OUTDOOR EDUCATION ON}

ENVIRONMENTAL LEARNING, APPRECIATION, AND ACTIVISM

A thesis submitted in partial fulfillment of the

requirements for the degree of

MASTER OF SCIENCE

in

ENVIRONMENTAL STUDIES

by

Jessica Okaty

2012 


\section{To: Dean Kenneth Furton}

College of Arts and Sciences

This thesis, written by Jessica Okaty and entitled The Effectiveness of Outdoor Education on Environmental Learning, Appreciation, and Activism, having been approved in respect to style and intellectual content, is referred to you for judgment.

We have read this thesis and recommend that it be approved.

Joel Heinen

Whitney Bauman

Raymond Scattone, Major Professor

Date of Defense: November 8, 2012

The thesis of Jessica Okaty is approved.

Dean Kenneth Furton
College of Arts and Sciences

Florida International University, 2012 


\section{DEDICATION}

I want to dedicate my thesis to my grandma, Nora Berman. She taught me to be kind, curious, to whistle, and countless other things. She spent hours taking me to dance, swimming, piano, and the park. I spent hours writing this thesis on her desk. Without her guidance, support, and endless love, I would not be the woman I am today. 


\section{ACKNOWLEDGMENTS}

I would like to sincerely thank the following people for their help and support: My major professor, Dr. Scattone, for all of his help and for never giving up on me.

Dr. Whitney Bauman and Dr. Joel Heinen, my committee members, for their knowledge and patience.

Angeline Low, the statistics angel, for all of her help with analysis and her fun stories. Melissa Ussa and Meenakshi Jerath for being great teachers and helping me collect data. Tricia Callahan, for reminding me that there's a light at the end of the tunnel (with wine). Chris Edwards for being a great lab partner, for advice, and statistical guidance. Alexandra Ricardel, for always reminding me that, "it's okay." Jenny Lopez, for helping me proofread and for celebrating with me. My parents, Rosalie and Anatole Okaty, for all of their love, guidance, and support. Cara Cooper, for inspiring me to learn more about our earth and being such a rock for me over the years.

My boyfriend, Zach Graham for easing my stress and making me laugh along the way. To all of my teachers who helped guide my learning experience to develop my knowledge to the place where it is today.

All of my family and friends who never stopped believing in me, even when I did, thank you. I could not have done this without all of you. 


\section{ABSTRACT OF THE THESIS \\ THE EFFECTIVENESS OF OUTDOOR EDUCATION ON ENVIRONMENTAL LEARNING, APPRECIATION, AND ACTIVISM}

by

Jessica Okaty

Florida International University, 2012

Miami, Florida

Raymond Scattone, Major Professor

The main objective of this research was to determine the effectiveness of outdoor education on student knowledge retention, appreciation for nature, and environmental activism in a college level course on south Florida ecology. Six class sections were given quizzes on four course topics either post-lecture or post-field trip. Students were also given pre-course and post-course opinion surveys. Although mean quiz scores for the post-field trip were higher than for the post-lecture, statistical analysis determined that there was no significant difference in quiz scores for location taken (post-lecture or postfield trip). Survey results show a correlation between knowledge of environmental issues and environmental activism. Even though student survey responses point to outdoor education and field trips being the most effective method of learning and influential on appreciation for nature, the quiz scores do not reflect such. 


\section{TABLE OF CONTENTS}

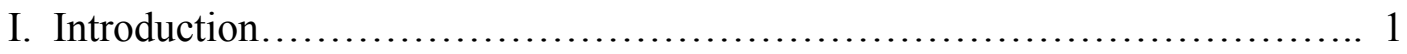

II. Literature Review..................................................... 4

A. Nature Deficit Disorder.......................................... 4

B. Environmental Literacy ....................................... 6

C. Environmental Education......................................... 8

D. Experiential Learning ........................................ 10

E. Outdoor Education.............................................. 13

F. Activism........................................................ 16

III. Methods and Procedures..................................................... 19

A. Participants and Study Area....................................... 19

B. Experimental Design......................................... 20

1. Study One: Knowledge Retention........................ 20

2. Study Two: Personal Opinion Survey ....................... 21

C. Statistical Analysis.............................................. 21

1. Analysis of Quiz Scores................................ 22

2. Analysis of Survey Responses........................... 22

a. Composite Scales................................ 22

b. Correlation......................................... 24

3. Percents and Frequency Comparison....................... 24

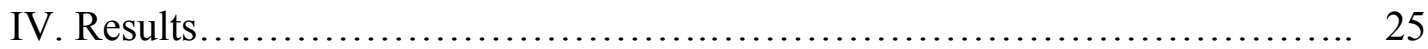

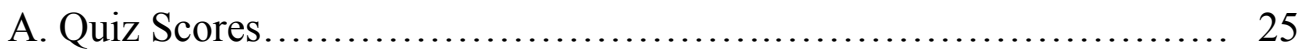

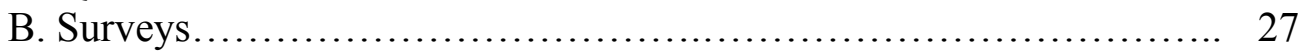

1. Reliability Scales..................................... 27

2. Mean Scores of Reliability Scales......................... 28

3. Correlations .......................................... $\quad 30$

4. Frequency and Percent Comparisons........................ 31

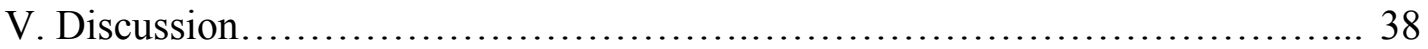

A. Knowledge Retention Study ................................ 38

B. Personal Opinion Study ....................................... 40

1. Mean Scores of Reliability Scales......................... 40

2. Correlations........................................... 41

3. Learning Styles....................................... 41

4. Outdoor Activities..................................... 42

5. Course Effectiveness................................... 43 
VI. Conclusion......................................................... 45

A. Summary of Research Results............................... 45

B. Suggestions for Future Research.............................. 46

C. Recommendations for Educators and Institutions.................. 48

D. Final Thoughts.......................................... 49

REFERENCES ...................................................... 51

APPENDICES............................................................. 56 


\section{LIST OF TABLES}

TABLE

1. Class sections and corresponding quiz locations for each topic....

2. Mean scores for topic and location.

3. Mean scores of reliability scales...................................... 29

4. Effectiveness scores for preferred learning styles............................. 29

5. Effectiveness score for preferred learning............................... 30 methods about south Florida ecosystems

6. Percent of student responses for learning style types........................ 32

7. Outdoor activity enjoyment responses............................... 32

8. Response percentages for outdoor activities that students enjoy $\ldots \ldots \ldots \ldots \ldots \ldots . \ldots 33$

9. Response percentages for likelihood of engaging........................... 34 in more outdoor activities in the future

10. Response percentages for course effectiveness question set................. 35

11. Response percentages for conservation efforts question................... 36

12. Response percentages for organizational involvement question............ 36 


\section{INTRODUCTION}

Evidence shows that immense global environmental problems exist that pose significant threats to humans and environmental health, and quality of life, such as global warming, pollution, and species diversity loss. Effective solutions to these problems require a well-educated society and professionals in the field (EPA, 1990). Most people are not aware of environmental problems and unknowingly live unsustainable lifestyles that are leading to environmental despair. The large majority of Americans are unaware that they know little about environmental problems or have misconceptions about them (Coyle, 1999). Some have a misconception that humankind will triumph because it historically has triumphed over many local crises, but this is the first truly global crisis (Orr, 1992). Many people now prioritize the economy over environment, which is a major change over the past decade from when people were more concerned with the environment (Jones, 2011). The economy is being prioritized over the environment in the midst of an environmental crisis. There is a nature deficit - a disconnect - between humans and their role in nature, and little public environmental literacy (Louv, 2005). Environmental education is needed to help the public with these problems, and outdoor education plays a key role in doing so. Only when an appreciation for nature is gained will people be motivated to address major environmental problems, and my thesis assumes that outdoor education will increase appreciation for nature in individuals.

Environmental education is a vital part of informing people about their relationship with their environment and their interdependence with nature. Outdoor education, a form of experiential education, plays a pivotal role in engaging students in the topics under discussion. However, many environmental education courses are taught 
in a way that does not include direct experiences with nature. My study analyzes the effectiveness of experiential learning via outdoor education as a method of environmental education in undergraduate level college ecology courses at Florida International University. The purpose of this study is to determine whether outdoor, place-based teaching is the most effective teaching style for environmental education. More specifically, I sought to find out if outdoor education leads to better understanding of course material and if students are more likely to act on environmental issues if they form a connection to nature through outdoor education.

There are four main objectives in this research. The first is to measure the retention of the subject knowledge of EVR3013L, Ecology of South Florida Lab, students over four ecosystem lessons involving place-based and lecture based pedagogies. Second, this thesis assesses students' appreciation for nature and environmental issues after taking the course. The third objective is to determine the most effective teaching method. The final objective is to find out if outdoor education has an effect on student's nature appreciation and environmental action. These objectives will be met by reviewing the course's effects on what knowledge the students have retained, whether or not the students have greater appreciation for nature and environmental issues, and if the students are more likely to take action.

My study hypothesizes that students will learn the material better as well as be more likely to act on the information they learn if they feel more connected to experiential or place-based learning. My experimental design focused on knowledge retention of students enrolled in the same course, with consistently similar lessons, as assessed through quizzes and surveys. My study will compare how students did on 
quizzes with or without an outdoor learning experience. This study also compares any changes from the pre-course survey to the post-course survey. Environmental educators and curriculum developers at an undergraduate level can use the information gathered to promote and design outdoor education programs. By comparing immediate understanding of the lessons for each ecosystem discussed both in the classroom and in the ecosystem itself, a better pedagogy for teaching this material will emerge. An underlying assumption of this study is that by engaging the students in the place that they are learning about, students will have direct experience to later reflect on, which should increase their understanding and appreciation of specific environments. 


\section{LITERATURE REVIEW}

This study encompasses a variety of aspects related to outdoor education, as discussed in the introduction. The literature review describes the current state of people's environmental connections through a discussion of nature deficit disorder and environmental literacy. The review explains how they can be overcome and improved upon by increasing people's environmental knowledge, appreciation, and activism. This chapter also describes outdoor education, a type of environmental and experiential education, as a method for increasing knowledge retention, appreciation, and activism.

\section{A. Nature Deficit Disorder}

Humans currently lack a connection with nature and evidence suggests that this disconnect may be considered a medical condition called nature deficit disorder (Louve, 2005). Mental and physical health benefits accrue from experiences and time spent in nature, which has become increasingly rare. Increased fear of outdoor play and technological advances has led to less and less time spent outside, which is a natural human occurrence. In fact, the biophilia hypothesis is the idea based on evolutionary history that humans have a natural need to connect with other living things (Wilson, 1984). Richard Louve stated, "Healing the broken bond between our young and nature is in everyone's self-interest, not only because aesthetics or justice demand it, but also because our mental, physical and spiritual health depend upon it” (Louve, 2005).

Most of the studies relating to nature deficit disorder involve children and very few involving adults. Children's ability to focus increases because of daily exposure to natural settings, and that focus enhances cognitive abilities, thus allowing students to 
learn better. (Wells, 2000) The increase in focus benefits learning ability for students with or without attention deficit disorder (ADD) or attention deficit hyperactive disorder (ADHD). Faber and Kuo studied data from weekly Internet surveys of 421 parents provided information about where their ( 5 to 18 year old) children played and the severity of their ADHD symptoms that week. The study found that the children who regularly played in natural settings had milder symptoms than the ones who played in an indoor or outdoor built setting (Faber Taylor \& Kuo, 2011). A further study involving seventeen 7 to 12 year olds diagnosed with ADHD studied the impacts of outdoor activity settings on concentration levels. Over a three-week period each child participated in a 20 minute guided walk in three different outdoor settings: an urban park, a downtown area, and a residential area. Each child took a concentration test after each walk and answered questions regarding their experience. The results found that concentration levels after walking in a park were higher than those after walking downtown or in a residential area. The study also found that the concentration increase was similar to two common types of ADHD medication and that the children also enjoyed the park walk experience the most (Faber Taylor \& Kuo, 2008).

Monitoring the Future was an annually conducted study from 1976 until 2005 among a nationwide sample of young adults, high school seniors, to analyze trends in environmental attitudes, beliefs, and behaviors. Data from the study, which included surveys of approximately 10,000 students, found that overall, environmental concerns have declined since the early 1990s. The students' willingness to participate in personal conservation efforts, like using less electricity, had a steep decline. (Wray-Lake, Flanagan \& Osgood, 2009). Unless concerns for environmental issues increase, 
environmentally responsible changes will not be made and environmental degradation will not cease.

In 2011, the Nature Conservancy held a nationwide survey of 602 teenagers between the ages of 13 and 17, which explored children's connection with nature, attitudes concerning the environment, and the opportunities or obstacles to their connecting with nature. The study found that $88 \%$ of children used a computer on a daily basis while $11 \%$ visited a natural area, illustrating that much of their time was spent using electronics indoors. However, $66 \%$ of children were found to have had a meaningful experience in nature. That $66 \%$ also preferred spending time outdoors, were interested in learning about the environment, and were concerned about environmental issues (The Nature Conservancy, 2011). Using a Nature Relatedness (NR) scale to assess the affective, cognitive, and experiential aspects of over 800 participants' connection to nature, researchers found that the NR score correlated with environmental scales, behavior, and frequency of time in nature. The NR stands out from similar scales in that it encompasses emotional, cognitive, and physical relationships whereas others only include one or two of these aspects. Further research found that the higher NR scores corresponded to more environmental concern and environmental behavior (Nisbet, Zelenski \& Murphy, 2009).

\section{B. Environmental Literacy}

Although the majority of Americans find that environmental issues and environmental education are important, the majority of people do not perform well on environmental literacy questionnaires (Coyle, 2005). Even though a person is concerned 
with environmental issues does not necessarily mean that it will be apparent in their behaviors (Kortenkamp \& Moore, 2001). Environmental literacy is the capacity to perceive, appropriately interpret, and value the specific state, dynamics, and potential of environmental system, as well as to take appropriate action to maintain, restore, or improve these states (Scholz, 2011). Ecological and environmental literacy is a factor that leads people toward environmental stewardship (Orr, 1992). In 2005, the EPA's Report to Congress on the Status of Environmental Education in the United States stated that the main challenge ahead in environmental education was to "raise the level of environmental literacy of the American citizenry as a whole" (EPA, 2005), a challenge that will be beneficial to the environment but that is a complicated and time consuming task.

Environmental literacy is a complex and time demanding process with many levels of understanding and development. The association for Environmental Education describes four facets of environmental literacy: Personal and civic responsibility, knowledge of environmental processes and systems, skills for understanding and addressing environmental issues, and questioning and analysis skills (EPA, 1990). Kevin Coyle believes that there are three levels of environmental literacy growth: environmental awareness (knowing about an issue, but not in detail), personal conduct knowledge (knowing enough about an issue to take personal action to help), and true environmental literacy (which involves imparting the subject's underlying principles, the skills needed to investigate the subject, and an understanding of how to apply that information) (Coyle, 2005). Outdoor education is a facet of education that plays a key role in restoring 
environmental literacy by increasing people's awareness of their own responsibilities to nature's balance through experiencing part of it (Smith, 1972).

\section{Environmental Education}

Enforcement was previously seen as the most important aspect of environmental management, but environmental education has now become an equal since it has been shown to increase environmental stewardship (EPA, 2005). Environmental Education offers the opportunity to improve the quality of life and surroundings for all forms of life (Rillo, 1985). By increasing public awareness about environmental issues, a better understanding of human's relationship with nature will be gained, thus benefiting the environmental crisis we are all faced with. According to the United National Environmental, Scientific, and Cultural Organization, "The goal of environmental education is to develop a world population that is aware of, and concerned about, the environment and its associated problems, and which has the knowledge, skills, attitudes, motivations, and commitment to work individually and collectively toward solutions of current problems and the prevention of new ones" (UNESCO, 1975). Since solving environmental problems and regeneration of damaged ecosystems can take an extremely long time, it is essential that young people are educated enough to continue where others have left off (Smith \& Williams, 1999).

Environmental education's main idea is to improve conservation by increasing public knowledge of ecological relationships to include humans instead of viewing themselves as outsiders (Smith, 1972). This sense of inclusion in nature was named ecological self, or ecological identity, by Arne Naess, who claims that greater self- 
connection with nature is pivotal in changing human behavior to be pro-environmental (Naess, 1973). The terms environmental education and conservation education may be used alternately in some instances, but both make reference to a similar idea of "ecological conscience" spoken of by Aldo Leopold and his widely accepted definition of conservation as "a state of harmony between men and land" (Smith, 1972).

David Orr suggests that, "all education is environmental education," and, "by what is included or excluded, students are taught that they are part of or apart from the natural world" (Orr, 1994). Thomas Rillo (1985) stated that outdoor education builds an experiential foundation, which is necessary for environmental education. Learners gain the awareness, knowledge, and skills to understand and solve environmental challenges because of their concern about the issues (EPA, 1990). However, some environmental educators have become frustrated to find that environmental education may increase students' environmental awareness, but students may show disinterest in participating in environmentally friendly efforts or only be interested in participating in initial efforts like recycling or using reusable bags (Jurin \& Fortner, 2002). This disinterest may be due to the complex and time intensive development process of environmental literacy discussed in the previous section, in which case more environmental education is necessary for those students to continue to expand their environmental literacy levels.

Even more than spreading knowledge of the subject and increasing concern, environmental education has many benefits for students. It has been shown that environmental education can benefit students' critical thinking, leadership, and relationship skills while improving self-discipline, focus, cognition, and health (American Forest Foundation, 2012; EPA, 2005). 


\section{Experiential Learning}

Learning cannot be viewed as a separate human function, but instead involves the entire being's functions of thinking, feeling, perceiving, and behaving. Kolb concluded in The Process of Experiential Learning (1984) that, "Learning is the process whereby knowledge is created through the transformation of experience." The process of experience is an active one which includes interactions with surroundings in one's lives,

not one in which they are merely a spectator (Smith, 1972). By learning about a subject in its environment or participating in an activity involving the subject, students become more engaged in the learning process because they can see how the information is relevant to their own lives.

Progressive education, such as experiential education, follows the idea that there is, "an intimate and necessary relationship between the process of actual experience and education." All experiences are not beneficially educative as they do not all contribute to connection to the information, positive attitudes, improving skills, or positive responses and may not be relevant to other experiences bridging the information between the two (Dewey, 1998). Therefore, it is important that educators take the students' experience into account when planning a lesson in order to make it the most beneficial experience possible.

To truly understand new information it must be connected to prior knowledge through personal reflection, a theme that comes across in most experiential learning techniques and theories (Jacobson, 2006). March and Wattchow (1991) found four critical phases to an expedition in adventure education: The conceptualization/dream phase, preparation phase, action/reality phase, and reporting/reflective/processing phase 
(Gair, 1997). The Kolb Cycle (which can be entered at any point) explains the process of experiential learning in four stages: having an experience/adventure, reviewing the experience, reflecting and drawing conclusions and planning for the future (Kolb, 1984). These views underscore the need for an experiential adventure.

An experiential foundation is necessary for a student to "know about their environment, to identify problems concerning the use of natural resources, to seek alternative solutions to environmental problems, and to be committed to taking action to alleviate these problems". This can be achieved through the experience of outdoor education (Rillo, 1985). In a technologically minded society, there are ways that technology and nature can be merged to give the participant a combination experience. For example, Project Noah is a website and phone application that allows users to identify species they see and save the coordinates through GPS so that others can find them. The application also consists of missions and maps. Collecting species data gives participants the ability to contribute to scientific studies through the process of uploading their photos to a map (Networked Organisms, 2012). The development of experiential learning has also led to specialized styles such as hands-on or active learning, cooperative learning, work-based learning, and service learning (Boss, 1999).

Experiential learning is memorable because it is different than typical passive, indoor, lecture based teaching methods. Hands-on learning style makes the experience personal and engages the learner both physically and emotionally during the learning process. Even though experiential learning is not currently a prevalent method of teaching, an ancient Chinese saying reminds us that this is not a new teaching method, "What I hear I forget, what I see I remember, what I do I understand." Howden (2012) 
compares this to teaching his child to ride a bike, in that the skill was achieved through the child's own experience, the personal attempts at riding, no matter how much coaching, talking, or demonstration he provided (Howden, 2012).

An interesting environmental, experiential study from 2010 was an 18- week research program called Connecting the Ocean, Reefs, Aquariums, Literacy, and Stewardship (CORALS). This study was designed to strengthen student understanding of coral reef decline by combining hands on experience with a coral tank in their classroom and making interactive videos about the process. The idea was that the mixture of activities would encourage students and give them the ability to manage environmental needs and contribute to sustainable development. Four high school science teachers from three different inland states participated in the study. The students examined different species of corals' growth at different temperatures and found that corals in higher temperatures grew slower and showed signs of bleaching. The activity increased student understanding of coral, other reef animals, and the effects caused by temperature increases engaging "students in a global issue that seemed removed from their lives inland." The students found that the experience made the information they had already learned more real and concrete. The students' "ocean-literacy" scores significantly increased because of the CORALS program.

In experimental learning, a setting is created through the learning experience to not only engage, but also to physically and mentally challenge the student so that they can overcome and reflect on the challenge as a basis for future actions (Howden, 2012). A recent study showed that children's connection to nature influences their interest in participating in nature-based activities and performing environmentally friendly 
behaviors. The study included 1,500 fourth-grade students in Brevard County, Florida who completed a survey after participating in an environmental education program. The researchers Cheng and Monroe (2010) found four main aspects to children's connection with nature: enjoyment of nature, empathy for creatures, sense of oneness, and sense of responsibility. The study found that the strongest predictor of a students' interest in participating in nature-based activities was their connection to nature. Student interest in partaking in environmentally friendly behaviors was also strongly influenced by their connection with nature, but also included previous nature experiences, their perceived control.

\section{E. Outdoor Education}

Outdoor education was defined by an early leader in outdoor education, Lloyd Burgess Sharp, as "all of that learning included in the curriculum in any subject matter area and at any grade level which can best learned outside the classroom" (Rillo, 1985). Evidence shows that learning about the natural environment from direct contact has more of an impact on learning that subject matter (Smith, 1972). Through outdoor education "connected knowing" occurs because the community becomes the classroom and the context of learning.

Outdoor education makes use of an outdoor environment, which can be natural or human made to encourage learning from experience for a variety of subject matters (Boss, 1999). However, outdoor education teaches about more than just nature, as it enhances other classroom curricula as well (Hammerman, 1973). A 2005 study found that after a week long residential outdoor education program there was a $27 \%$ increased in 
"mastery of science concepts; enhanced cooperation and conflict resolution skills; gains in self esteem; gains in positive environmental behavior; and gains in problem-solving, motivation to learn, and classroom behavior" (American Institutes for Research, 2005; Chawla, 2006).

The outdoor experience and personal connection taken from the experience must also be a focus in outdoor education, rather than just cognitive development. A European study examining children's emotional connection with nature and their willingness to protect it involved 400 high school junior and senior students in both urban and rural Germany and Lithuania (Mueller, Kals \& Pansa, 2009). The students were surveyed to assess their emotional affinity toward nature, environmental risk awareness, contact with nature, and willingness to pro-environmental commitment. Researchers found that students' willingness for pro-environmental commitment was significantly predicted by emotional affinity toward nature, and indirectly impacted by contact with nature because it develops emotional affinity.

Effective outdoor learning is said to include observation, research, and reflection. By observing the subject material directly, students gain interest and curiosity in that subject. Reflection on the experience and what was learned leads to understanding and appreciation (Rillo, 1985) much like how the experience of watching "a fierce green fire" dying in a wolf's eyes acted as a turning point for how Aldo Leopold viewed the wolf, mountain, and his connection with them, which he reflected on for the rest of his life (Orr, 1994). A direct personal contact with nature can give students understanding and deeper meaning to the necessary interrelationships that are clearly established in nature, but may not be apparent when studying the same thing in a laboratory setting (Gabrielsen 
\& Holtzer, 1965). Nadelson and Jordan describe field trips as, "effective because they situate learning and facilitate knowledge transfer, thereby influencing students learning attitudes, interests, and motivation.” A study of $6^{\text {th }}$ grade students found that when surveyed immediately after a field trip, as well as a month after, students held positive attitudes toward the field trip and recalled a hands-on orienteering activity most frequently (Nadelson \& Jordan, 2012).

Judith Boss (1999) describes three types of outdoor education: Service learning, cultural journalism and participatory research, and adventure education. Service learning incorporates community service, which may be short or long term projects that benefit the community directly from the project and indirectly by instilling the students with a sense of civic value or worth. Cultural journalism and participatory research provides a basis for cooperation by developing a deeper understanding of civic traditions. Adventure education is when outdoor activities that encompass some amount of risk, students develop self-confidence and a connection to nature by overcoming challenges. (Boss, 1999)

For many people, stepping outside of their comfort zone enables them to learn best, and the key to outdoor education may be found in the achievement one feels from overcoming obstacles that they do not normally face (Gair, 1997). Studies have also shown that people learn better when information is obtained through a specific type of learning style. Sensory-based learning styles are classified as auditory, visual, and kinesthetic (Ladue, 2002). Many outdoor education programs encompass all of these styles throughout the experience. 
Unfortunately, many schools do not have a natural area on the property available for outdoor, environmental education, which indirectly teaches students about environmental preservation. Since students learn from what schools do in addition to what they say, choosing not to preserve natural areas on school or campus grounds sets an precedent for students that natural lands are expendable (Orr, 1994). In a study involving 45 elementary, middle, and high schools in the Toronto school district, surveys regarding the impact of green school initiatives were conducted on 150 parents, teachers, and principles. Despite the variety of schools, $90 \%$ of participants reported increased student enthusiasm and engagement in learning on green school grounds when compared to indoor teaching (Dyment, 2005). However, since outdoor education is typically different from the normal teaching methods that students are used to, adjustments may be necessary for students to receive the full benefits. For example, after the Belfountain Public School in Caledon, Ontario (a small, rural school with 170 students and 10 full time teaching staff) implemented an outdoor education program, the students were immediately distracted after a few minutes being outside. Overall, however, students gained experience through incremental learning and became comfortable enough in the outdoor environment to allow the program to develop into an integrated learning program (Gibson, 2010).

\section{F. Activism}

Improvements to the current environmental crisis require human lifestyles to change, which requires active citizenry. For students to become active citizens they will need to understand their place in ecology, including the benefits and responsibilities that 
place implies. (Boss, 1999) John Dewey, a leader in progressive and experiential education, believed that learning was active and that education should give students real experiences to give them the skills and ability to be an active citizen and positively contribute to society. (Neil, 2005) David Orr argued that environmental collapse should be taught while empowering students with skills and personal connections to environmental issues (Orr, 2004).

Outdoor experiences, specifically educational experiences, have been shown to increase students' appreciation for nature, connection with nature, and willingness to participate in environmental activism. A study examining how college students' environmentally responsible behaviors related to visiting natural areas on campus showed that out of 115 students, $76.5 \%$ had visited a natural area and about half of those were visiting for a class. Out of the students who visited a natural area, environmental responsibility was related to the frequency of their visits and was stronger for the students who visited for a class (Lawrence, 2012).

A child's direct experience with nature and environmental mentoring from someone close to the child are the two most significant factors contributing to that child's environmental activism as an adult (Chawla, 2006). A study on the relationship between indirect and direct nature experiences and children's environmental knowledge, attitudes, and behavior used surveys, focus groups, and observations to evaluate the experiences of 108 middle and high school students participated in an international immersion environmental education program, as well as a control group of 49 students who did not participate. The program had a preparatory program (indirect nature experience), a 7-14 day international field workshop (direct nature experience), and a post-trip service project. The study found 
that students that participated in a direct nature experience had a significant increase in knowledge compared to the control group. Researchers discovered that while children's indirect experiences led to improved environmental knowledge, their direct experiences led to environmental attitude and behavior development (Duerden \& Witt, 2010).

Although outdoor education may not be the only facet involved in solving environmental problems, it is an important step in increasing environmental literacy and environmental activism. 


\section{Methods and Procedures}

This study explores outdoor education as a means of improving students' environmental knowledge, appreciation, and activism. The methods used in this study analyze include quizzes and surveys. The purpose of this chapter is to introduce the design of the study, the procedures used for data collection and methods for data analysis.

\section{A. Participants and Study Area}

This study took place at Florida International University in six EVR3013L (Ecology of South Florida Lab) classes during the Summer 2012 semester. There were 57 students involved in the study at the beginning and 50 by the end since seven students dropped the course. I have chosen to use six sections of lab taught during the summer of 2012 for purposes of convenience. The three teaching assistants assigned to the summer were experienced in teaching the course, including myself. ${ }^{1}$ In addition, EVR3013L is a course that offers many outdoor learning opportunities by teaching information about key South Florida ecosystems and taking field trips to those locations. It is a great course for studying both outdoor education and in-class lectures. The field trips/ecosystems that were visited include pine rockland, tropical hardwood hammock, sawgrass prairie, sand pine scrub, pine flatwood, seagrass beds, coral reefs, and mangrove forests. My study focused on college students engaging in learning about the ecology of their local environment, south Florida, and for some students was their first time experiencing the ecosystems around where they live. The course is a life science option for the required natural science course for undergraduate core curriculum, so students come from a

\footnotetext{
${ }^{1}$ Teaching assistants involved in this study were Meenakshi Jerath, Melissa Ussa, and Jessica Okaty.
} 
variety of majors but selected this course from fourteen options. Most of the

environmental education research studies involve children and some involve adolescents, but very little regard college students or adults. My study aims to find out more about college level students.

\section{B. Experimental Design}

\section{Study One: Knowledge Retention}

My study consists of two comparison studies that took place during Summer 2012: knowledge retention quizzes and a personal opinion survey. In the knowledge retention study students from 6 sections of the same course, "Ecology of South Florida Lab," were given short, five question quizzes to test their short-term retention of knowledge from a lesson with a topic covering specific ecosystems. The variable "topic" is used throughout the study to indicate the subject material covered in the lectures, field trips, and corresponding quizzes. Topics included Everglades National Park (ENP), Bill Baggs State Park (BBSP), Jonathan Dickinson State Park (JDSP), and Florida Keys National Marine Sanctuary (FKNMS). The classes each took four quizzes, each corresponding to a lesson topic. The class alternated taking two quizzes after an indoor, lecture-based lesson (post-lecture) and two after a field trip or outdoor, place-based lesson (post-field trip). In this study, "location" is the name given to the variable that specifies whether the quiz was taken post-lecture or post-field trip. For each topic covered, three class sections took a quiz post-lecture and three took a quiz post-field trip. The quizzes were graded on a scale of zero to five. The variable "scores" is used 
throughout the study to indicate the quiz score, or grade. The following table shows the six sections and their corresponding quiz schedule. Quizzes are attached in Appendix 1.

Table 1.

Class sections and corresponding quiz locations for each topic

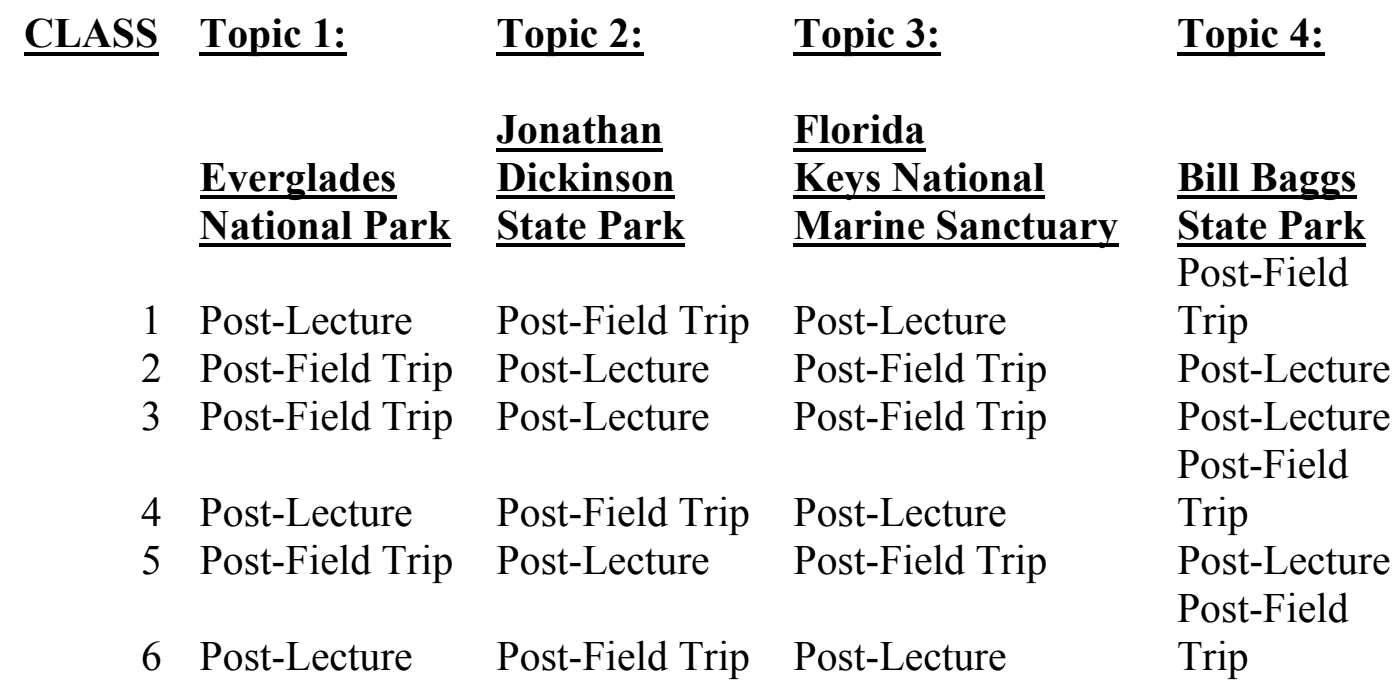

\section{Study Two: Personal Opinion Survey}

The second comparison study involved student pre-course surveys and postcourse surveys, given on the first and last day of the course respectfully. The surveys asked students about their outdoor activity preferences, appreciation for nature, learning preferences, connection to nature, experience in the course, and likelihood of participating in environmental activism (personal or group). For a complete list of survey questions see Appendix 2.

\section{Statistical Analysis}

For all of the studies, data was analyzed using SPSS software, originally called Statistical Package for Social Sciences. SPSS is statistical analysis software commonly 
used in scientific fields. The software is a user-friendly software that can be used for variety of statistical tests.

\section{Analysis of Quiz Scores}

An independent samples t-test was conducted to test to measure statistical significant difference between scores of quizzes taken post-lecture and quizzes taken post-field trip. A $4 \times 2$ ANOVA $^{2}$ was conducted to evaluate the effects of four topics and two locations (post-lecture and post-field trip) on quiz scores. After splitting the file by location, an independent samples t-test was conducted to examine quiz scores in relation to each quiz topic.

\section{Analysis of Survey Responses}

\section{a. Composite Scales}

A reliability test for Cronbach's Alpha* was performed for pre-course and postcourse survey question sets regarding environmental knowledge, conservation efforts, organizational involvement, and activism. In addition the post-course survey also includes a question set on course effectiveness. The reliability test was used to see if the questions were compatible and had acceptable levels of similarity. If Cronbach's Alpha level was acceptable, a composite scale was created for the question set and a score was given.

In the Knowledge scale, for pre-course and post-course surveys, students answered "How much do you know about each of the following: conservation, climate change, natural resources \& management, south Florida ecology, environmental

\footnotetext{
${ }^{2}$ ANOVA is the Analysis Of Variance, a statistical test used for cases where there are more than two groups.
} 
legislation" with either "a lot," "a good amount," "a little," or "nothing." The choices were each given a score of 4 to 1 respectively.

On both the pre-course and post-course surveys, questions asking "How likely are you to participate in the following conservation efforts: Recycling, conserving water, choosing more sustainable transportation, adopting a more sustainable diet, using less energy, reducing consumption (buying less/borrowing) and buying used or recycled products" and "How likely are you to get involved with an environmental organization by donating, signing a petition, attending a meeting, volunteering, attending an event, participate in non-violent direct action, and joining" were asked. The response options for both questions were "Very Likely," "Likely," "Neutral," "Unlikely," and "Very Unlikely." These Likert scales were given a score of 5 to 1 respectfully. Both of these question sets were combined for the overall activism score.

On the post-course survey, students were asked to "Choose the option that most closely reflects how you feel about the following: I enjoyed the field trips for this course, Field trips contributed to my understanding of the course information, I feel more connected to nature since taking this course, I feel more connected to south Florida ecosystems since visiting them, my concern for environmental issues has increased since taking this course, and I feel the need to be more environmentally responsible since taking this course." The response options for each of these are "Strongly Agree," "Agree," "Neutral," "Disagree," and "Strongly Disagree." To read these questions as they are written in the survey, see Appendix 2. 


\section{b. Correlation}

A Pearson's Correlation was performed to compare knowledge score with personal conservation efforts, organization participation efforts, and overall activism score. This relationship test is typically used to compare sets of questions with acceptable reliability results from Cronbach's Alpha by measuring their correlation (linear dependence) between two variables. The results will give information about how knowledge affects students' environmental activism.

\section{Percent and Frequency Comparisons}

Frequencies and percentages from the pre-course and post-course surveys were reviewed for questions regarding subject participation in outdoor activities, organizational involvement, and preferred learning styles. The variables were analyzed separately for the pre-course survey and post-course surveys because no identifier was used to match each student's pre-course survey to their post-course survey. The mean course effectiveness score was also reviewed for different types of learning styles. 


\section{RESULTS}

As described in the previous methods and procedures chapter, my thesis contains two studies: knowledge retention quizzes and personal opinion surveys. The data from both studies were analyzed using SPSS statistical software. The purpose of this chapter is to explain the tests and frequency comparisons used to understand the data. It also draws conclusions from the results as well, but are expanded upon in detail in the discussion section that follows.

\section{A. Quiz Scores}

The independent samples t-test revealed no statistical significant difference in the means of quiz scores for quizzes taken post-lecture $(\mathrm{M}=3.46, \mathrm{SD}=1.09)$ and quizzes taken post-field trip $(\mathrm{M}=3.56, \mathrm{SD}=1.06)$. Taking the quizzes after the lecture of after the field trip had no statistically significant effect on the quiz scores. Although the mean quiz score taken after the field trip was higher than after the class lecture, there was not a large enough difference to be statistically significant. The post-lecture and post field trip means for quiz scores can be found in Figure 1. 
Figure 1.

Quiz scores by location

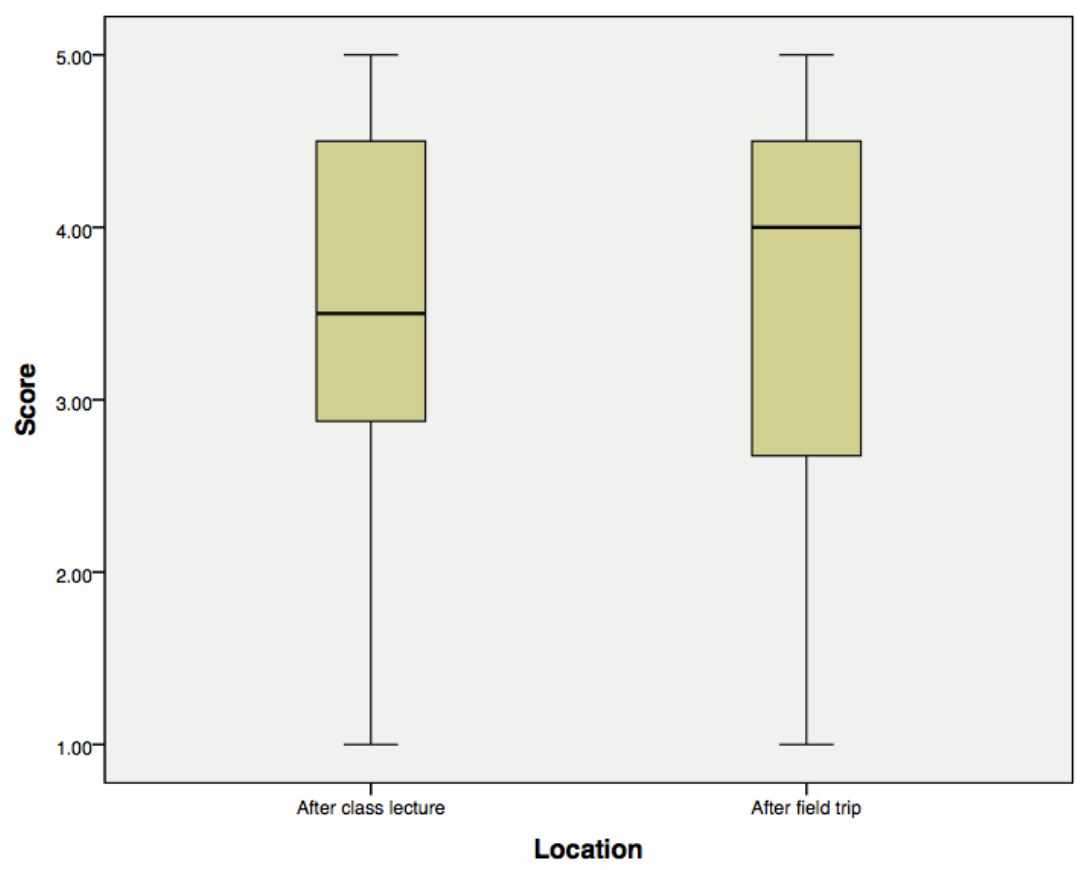

The 4 x 2 Analysis of Variance (ANOVA) indicated no significant interaction between topic and location (post-lecture or post-field trip), $\mathrm{F}(3,170)=.984, \mathrm{p}=.402$, but significant for the main effect of quiz $F(3,170)=12.736, p<.001$, partial $\eta^{2}=.18$. The means and standard deviations for quiz scores as a function of the two factors are presented in Table 2. Post hoc tests using Fisher's LSD procedure at .05 indicated that the mean SCORE for Bill Baggs State Park $(\mathrm{M}=4.23, \mathrm{SD}=.69)$ was significantly higher than Everglades National Park $(\mathrm{M}=3.31, \mathrm{SD}=1.20)$, Jonathan Dickinson State Park $(\mathrm{M}$ $=2.98, \mathrm{SD}=.91)$, and Florida Keys National Marine Sanctuary $(\mathrm{M}=3.55, \mathrm{SD}=1.03)$. Additionally, the mean score for Florida Keys National Marine Sanctuary was significantly higher than Jonathan Dickinson State Park. This quiz main effect indicated 
that the student's scores tended to be higher for the Bill Baggs State Park field trip than for the other trips, but this was not the focus of this study.

The independent samples t-test conducted after splitting the file by location revealed no statistical significant difference in the means of quiz scores for quizzes taken post-lecture and quizzes taken post-field trip. The means and standard deviations for quiz scores post-lecture and post-field trip for each topic are presented in Table 2.

Table 2.

Mean scores for topic and location

\begin{tabular}{|l|l|l|l|}
\hline Quiz Topic & Location & Mean Score & $\begin{array}{l}\text { Standard } \\
\text { Deviation }\end{array}$ \\
\hline Everglades National Park & Post- Lecture & 3.23 & 1.14 \\
\cline { 2 - 4 } & Post- Field Trip & 3.44 & 1.32 \\
\hline \multirow{2}{*}{$\begin{array}{l}\text { Jonathan Dickinson State } \\
\text { Park }\end{array}$} & Post- Lecture & 3.20 & .99 \\
\cline { 2 - 4 } & Post- Field Trip & 2.77 & .80 \\
\hline \multirow{2}{*}{$\begin{array}{l}\text { Florida Keys National } \\
\text { Marine Sanctuary }\end{array}$} & Post- Lecture & 3.49 & 1.12 \\
\cline { 2 - 4 } Bill Baggs State Park & Post- Field Trip & 3.60 & .95 \\
\cline { 2 - 4 } & Post- Lecture & 4.28 & .73 \\
\cline { 2 - 4 } & Post- Field Trip & 4.21 & .69 \\
\hline
\end{tabular}

\section{B. Surveys}

\section{Reliability Scales}

In the pre-course survey, Cronbach's Alpha was used and the Knowledge scale was found have acceptable reliability ( 6 items; $=.76$ ), the Conservation efforts scale was found to have good reliability ( 7 items; .83), the Environmental Organization Involvement scale was found to have good reliability $(7$ items; $=.83)$ Using Cronbach's Alpha, the Activism scale was found to have very good reliability (14 items; $=.88)$.

In the post-course survey, using Cronbach's Alpha, the Course Effectiveness scale was found to have good reliability ( 6 items; $=.85$ ), the Knowledge scale was found to have good reliability ( 6 items; $=.83$ ), the Conservation Efforts scale was found to have 
very good reliability (7 items; = 8.75), Environmental Organizations Involvement had good reliability $(7$ items; $=.82)$, and overall Activism scale had very good reliability $(14$ items; $=.88)$.

All of the scales had either good or very good reliability; the questions were compatible and had acceptable levels of similarity. Since Cronbach's Alpha level was acceptable, a composite scale was created for the question set and a score was given to the overall question set.

\section{Mean Scores of Reliability Scales}

The scales and their corresponding means and standard deviations for the precourse survey and post-course survey can be found in Table 3. Statistical significance could not be tested for because there were no student identifiers, however the means can be viewed to see if there is any change in the mean score. The means of these reliability scales reveal that on average, when asked about their knowledge of environmental issues, students felt they knew between "a little" and "a good amount" both in the pre-course survey as well as the post-course survey, but the mean scores did increase slightly from 2.43 to 2.78 from pre to post survey. The mean scores for students' likeliness of participating in conservation efforts increased from 4.07 to 4.27 , although both fall between "likely" and "extremely likely" on the Likert scale. When asked about how likely they were to get involved with an environmental organization, students were less than likely but more than neutral with a pre- course survey mean of 3.74 and post-course survey mean of 3.81 . 
Table 3.

Mean scores of reliability scales.

\begin{tabular}{|l|l|l|}
\hline SCALE & $\begin{array}{l}\text { PRE-SURVEY MEAN } \\
\text { (Standard Deviation) }\end{array}$ & $\begin{array}{l}\text { POST-SURVEY MEAN } \\
\text { (Standard Deviation) }\end{array}$ \\
\hline $\begin{array}{l}\text { Knowledge of } \\
\text { Environmental Issues }\end{array}$ & $2.43 \pm .45$ & $2.78 \pm .49$ \\
\hline Conservation Efforts & $4.07 \pm .70$ & $4.27 \pm .66$ \\
\hline $\begin{array}{l}\text { Environmental } \\
\text { Organization Involvement }\end{array}$ & $3.74 \pm .77$ & $3.81 \pm .70$ \\
\hline $\begin{array}{l}\text { Activism (Conservation } \\
\text { Efforts \& Organizational } \\
\text { involvement) }\end{array}$ & $3.89 \pm .67$ & $4.04 \pm .59$ \\
\hline $\begin{array}{l}\text { Course Effectiveness } \\
\text { N/A }\end{array}$ & $4.41 \pm .54$ \\
\hline
\end{tabular}

Mean course effectiveness was 4.41 in the post-course survey. Effectiveness scores were compared with each of the responses to questions about students' preferred learning styles or methods. By viewing the effectiveness score by the students' preferred learning style, it should show if students thought the course was more effective because they prefer active, experiential learning. Table 4 shows the mean effectiveness scores for the students who chose each different learning style in response to the question "I learn a subject best when...". The differences between the effectiveness scores is small, however the largest score applies to the student response, "I participate in an activity involving it" which presents some indication that students who prefer to learn through an activity may have found the course more effective than students who prefer other learning styles.

Table 4.

Effectiveness score for preferred learning styles

\begin{tabular}{|l|l|}
\hline Learning Style & Effectiveness Score \\
\hline I listen to information about it & 4.42 \\
\hline I watch a video or demonstration of it & 4.37 \\
\hline I read about it & 4.33 \\
\hline I write something about it & 4.40 \\
\hline I participate in an activity involving it & 4.51 \\
\hline
\end{tabular}


Effectiveness scores were also sorted by students' response to their preferred method of learning about south Florida ecosystems specifically. Table 5 shows the corresponding effectiveness scores for each learning method chosen. Once again, the highest effectiveness scores corresponded with the responses that involved active learning, "In class activities" with 4.48 and "Field Trips" at 4.54, indicating that students who prefer experiential learning methods found the class to be the most effective.

Table 5 .

Effectiveness score for preferred learning methods about south Florida ecosystems.

\begin{tabular}{|l|l|}
\hline Ecology Learning Method & Effectiveness Score \\
\hline In class lectures & 4.31 \\
\hline In class videos & 4.16 \\
\hline In class activities & 4.48 \\
\hline Self-guided Study & 4.29 \\
\hline Field Trips & 4.54 \\
\hline
\end{tabular}

\section{Correlations}

For the pre-course survey, correlation coefficients were computed among the Knowledge, Conservation Efforts, Environmental Organization Involvement, and Activism scores. Knowledge was not found to be statistically significantly correlated with Conservation Efforts score, $\mathrm{p}=.63$, Environmental Organization Involvement $\mathrm{p}=.96$, or overall activism, $\mathrm{p}=.70$, at the .05 alpha level. Before the course was taken, students' knowledge of environmental issues was not related to students' likeliness of taking environmental action, whether it is personal conservation efforts or environmental organization involvement.

For the post-course survey, correlation coefficients were also computed among the Knowledge, Conservation Efforts, Environmental Organization Involvement, and Activism scores. Knowledge was found to be statistically significantly correlated with 
Activism at the .05 alpha level, $\mathrm{r}=.29, \mathrm{p}=.04$ and with Conservation Efforts at the .01 alpha level, $\mathrm{r}=.36, \mathrm{p}=.01$, but there was no significance with Environmental Organization Involvement, $\mathrm{p}=.36$. These results show that after the course, as students' assumed knowledge increased so did their interest in overall activism and conservation efforts.

\section{Frequency and Percent Comparisons}

\section{a. Learning Styles}

In the pre-course survey and post-course survey students were asked to chose the method in which they learn a subject best. The results from the question were used to gauge the students' preferences to active or experiential learning, which is the basis of outdoor education. Since is it asked before and after the course it will also see if the percent of students have changed their preferred learning styles after engaging and an experiential, place-based, outdoor learning course. The style with the highest percentage in both pre-course and post-course surveys was the active learning response, but it did decrease slightly from $47.4 \%$ in the pre-course survey and $46 \%$ in the post course survey. Table 6 shows the percent of students' responses to the question preface "I learn a subject best when..." with each type of learning style they chose. Some students chose more than one response for this question. 
Table 6.

Percent of student responses for learning style types

\begin{tabular}{|l|l|l|}
\hline Learning Style & $\begin{array}{l}\text { Response Percent } \\
\text { (Pre-course survey) }\end{array}$ & $\begin{array}{l}\text { Response Percent } \\
\text { (Post-Course Survey) }\end{array}$ \\
\hline I listen to information about it & 17.5 & 30 \\
\hline $\begin{array}{l}\text { I watch a video or demonstration } \\
\text { about it }\end{array}$ & 29.8 & 34 \\
\hline I read about it & 24.6 & 12 \\
\hline I write something on it & 8.8 & 12 \\
\hline $\begin{array}{l}\text { I participate in an activity involving } \\
\text { it }\end{array}$ & 47.4 & 46 \\
\hline Other & 3.5 & 1 \\
\hline
\end{tabular}

\section{b. Outdoor Activities}

Students were asked a few different questions regarding their outdoor activities in both the pre-course and post-course surveys. First and foremost, students were asked if they enjoy outdoor activities using a five point Likert scale, ranging from strongly agree to strongly disagree. The results for this question show that students seem to enjoy outdoor activities more after taking the Ecology of South Florida course than they did before taking it. The results for each response are shown in Table 7.

Table 7.

Outdoor activity enjoyment responses

\begin{tabular}{|l|l|l|}
\hline Response & $\begin{array}{l}\text { Pre-Course Survey } \\
\text { Percentage }\end{array}$ & $\begin{array}{l}\text { Post-Course Survey } \\
\text { Percentage }\end{array}$ \\
\hline Strongly Agree & 45.6 & 56 \\
\hline Agree & 40.4 & 38 \\
\hline Neutral & 12.3 & 6 \\
\hline Disagree & 1.8 & 0 \\
\hline Strongly Disagree & 0 & 0 \\
\hline
\end{tabular}

The students were also asked to identify what sorts of outdoor activities they enjoy, in order to see whether students enjoy the outdoor activities that are involved in the class before taking the course and see if more students enjoy those activities after 
taking the course. Walking/hiking was the highest preferred activity and it is also one the activities that students participated in during the course. The activity choices that are involved in the course include "walking/hiking," "boating," "nature/wildlife watching," and "snorkeling/diving." From the pre-course survey to the post-course survey, the responses from "walking/hiking" and "boating" were approximately the same, "nature/wildlife watching" decreased from 50.9\% to $46 \%$, and "snorkeling/diving" increased from $52.6 \%$ to $66 \%$. The responses for the students who chose the "other" option listed the outdoor activities that they enjoy to be "sports," "jet skiing," "snowboarding," and "swimming." There was one response for "none" in the pre-course survey, but there were none in the post-course survey. Table 8 displays the outdoor activity choices and the percent of students whom chose that they enjoyed them for the pre-course survey as well as the post-course survey.

Table 8.

Response percentages for outdoor activities that students enjoy

\begin{tabular}{|l|l|l|}
\hline Outdoor Activity & $\begin{array}{l}\text { Pre-Course Survey } \\
\text { Percentage }\end{array}$ & $\begin{array}{l}\text { Post-Course Survey } \\
\text { Percentage }\end{array}$ \\
\hline Biking & 68.4 & 66 \\
\hline Walking/hiking & 78.9 & 78 \\
\hline Fishing & 38.6 & 42 \\
\hline Hunting & 14 & 24 \\
\hline Boating & 50.9 & 52 \\
\hline Canoeing/Kayaking & 45.6 & 50 \\
\hline Nature/Wildlife watching & 50.9 & 46 \\
\hline Snorkeling/Diving & 52.6 & 66 \\
\hline Camping & 42.1 & 50 \\
\hline Climbing & 24.6 & 26 \\
\hline Horseback Riding & 35.1 & 46 \\
\hline Surfing/Wakeboarding & 77.2 & 28 \\
\hline Skateboarding & 17.5 & 22 \\
\hline None & 1.8 & 0 \\
\hline Other & 1.8 & 10 \\
\hline & &
\end{tabular}


Students also answered a question on the pre-course and post-course surveys asking if they are likely to change the amount of outdoor activities they partake in. This question is meant to see if there is any change in the students' interest in outdoor activity participation. There were no students who chose the "likely" or "very likely to engage in less activities" options. The "likely to engage in the same amount" option decreased by $14.1 \%$. There was an increase in the responses "very likely to engage in more" by $7.9 \%$ and "likely to engage in more" by $3.4 \%$. The percentages are found below in Table 9 .

Table 9.

Response percentages for likelihood of engaging in more outdoor activities in the future

\begin{tabular}{|l|l|l|}
\hline Response & $\begin{array}{l}\text { Pre-Course Survey } \\
\text { Percentage }\end{array}$ & $\begin{array}{l}\text { Post-Course Survey } \\
\text { Percentage }\end{array}$ \\
\hline Very likely to engage in more & 28.1 & 36 \\
\hline Likely to engage in more & 38.6 & 42 \\
\hline $\begin{array}{l}\text { Likely to engage in the same } \\
\text { amount }\end{array}$ & 28.1 & 14 \\
\hline Likely to engage in less & 0 & 0 \\
\hline Very likely to engage in less & 0 & 0 \\
\hline
\end{tabular}

In order to see if students' interest in participating in outdoor activities was affected by the Ecology of South Florida lab, they were asked if the course had an influence on their outdoor activity. An overwhelming $74 \%$ of the responses were "Yes, Positive Influence" while 16\% chose "No," it did not influence their outdoor activity amount, and $10 \%$ were "Unsure." There were no students who responded with "Yes, Negative Influence.”

\section{c. Course Effectiveness}

The effectiveness scale - from question 14 in the post survey (Appendix 2) included questions about field trips, connection with nature, environmental concern, and environmental responsibility. For all of these questions, more than $75 \%$ of the responses 
were either "Agree" or "Strongly Agree." This high percentage indicates that students perceived the course to be highly effective. Table 10 displays the percent of students' responses to the specific statements about course effectiveness.

Table 10.

Response percentages for course effectiveness question set

\begin{tabular}{|l|l|l|l|l|l|}
\hline Statement & $\begin{array}{l}\text { Strongly } \\
\text { Agree }\end{array}$ & Agree & Neutral & Disagree & $\begin{array}{l}\text { Strongly } \\
\text { Disagree }\end{array}$ \\
\hline $\begin{array}{l}\text { I enjoyed the field trips for } \\
\text { this course }\end{array}$ & 56 & 40 & 4 & 0 & 0 \\
\hline $\begin{array}{l}\text { Field trips contributed to my } \\
\text { understanding of the course } \\
\text { information }\end{array}$ & 62 & 34 & 4 & 0 & 0 \\
\hline $\begin{array}{l}\text { I feel more connected to } \\
\text { nature since taking this course }\end{array}$ & 52 & 30 & 14 & 4 & 0 \\
\hline $\begin{array}{l}\text { I feel more connected to south } \\
\text { Florida ecosystems since } \\
\text { visiting them }\end{array}$ & 60 & 34 & 4 & 2 & 0 \\
\hline $\begin{array}{l}\text { My concern for } \\
\text { environmental issues has } \\
\text { increased since taking this } \\
\text { course }\end{array}$ & 42 & 42 & 12 & 4 & 0 \\
\hline $\begin{array}{l}\text { I feel the need to be more } \\
\text { environmentally responsible } \\
\text { since taking this course }\end{array}$ & 48 & 38 & 12 & 2 & 0 \\
\hline
\end{tabular}

Students were asked questions on the pre-course survey and the post-course surveys regarding their likeliness of participating in environmental activism, and were split into two sets of questions. One set asked, "How likely are you to participate in the following conservation efforts?" and the other set asked, "How likely are you to get involved with an environmental organization by..." for which the responses involved group environmental actions. Responses to these sets of questions are shown in both Table 11 and Table 12. 
Table 11.

Response percentages for conservation efforts question

\begin{tabular}{|c|c|c|c|c|c|c|}
\hline Statement & Survey & $\begin{array}{l}\text { Very } \\
\text { Likely }\end{array}$ & Likely & Neutral & Unlikely & $\begin{array}{l}\text { Very } \\
\text { Unlikely }\end{array}$ \\
\hline \multirow[t]{2}{*}{ Recycling } & Pre-Course & 59.6 & 31.6 & 3.5 & 1.8 & 3.5 \\
\hline & Post-Course & 62 & 30 & 4 & 0 & 4 \\
\hline \multirow[t]{2}{*}{ Conserving Water } & Pre-Course & 49.1 & 29.8 & 15.8 & 3.5 & 1.8 \\
\hline & Post-Course & 52 & 40 & 8 & 0 & 0 \\
\hline \multirow{2}{*}{$\begin{array}{l}\text { Choosing more } \\
\text { sustainable } \\
\text { transportation }\end{array}$} & Pre-Course & 40.4 & 35.1 & 15.8 & 3.5 & 1.8 \\
\hline & Post-Course & 46 & 34 & 12 & 6 & 2 \\
\hline \multirow{2}{*}{$\begin{array}{l}\text { Adopting a more } \\
\text { sustainable diet }\end{array}$} & Pre-Course & 40.4 & 35.1 & 15.8 & 3.5 & 1.8 \\
\hline & Post-Course & 40 & 40 & 14 & 2 & 2 \\
\hline \multirow[t]{2}{*}{ Using less energy } & Pre-Course & 38.6 & 38.6 & 14 & 5.3 & 3.5 \\
\hline & Post-Course & 54 & 34 & 8 & 4 & 0 \\
\hline \multirow{2}{*}{$\begin{array}{l}\text { Reducing } \\
\text { consumption (buying } \\
\text { less/borrowing) }\end{array}$} & Pre-Course & 31.6 & 35.1 & 21.1 & 8.8 & 1.8 \\
\hline & Post-Course & 38 & 44 & 16 & 0 & 2 \\
\hline \multirow{2}{*}{$\begin{array}{l}\text { Buying used/recycled } \\
\text { products }\end{array}$} & Pre-Course & 40.4 & 31.6 & 24.6 & 0 & 1.8 \\
\hline & Post-Course & 40 & 40 & 16 & 2 & 2 \\
\hline
\end{tabular}

Table 12.

Response percentages for organizational involvement question

\begin{tabular}{|l|l|l|l|l|l|l|}
\hline Statement & Survey & $\begin{array}{l}\text { Very } \\
\text { Likely }\end{array}$ & Likely & $\begin{array}{l}\text { Neutra } \\
\text { I }\end{array}$ & Unlikely & $\begin{array}{l}\text { Very } \\
\text { Unlikely }\end{array}$ \\
\hline Donating & Pre-Course & 31.6 & 38.6 & 14.0 & 8.8 & 7.0 \\
\cline { 2 - 7 } & Post-Course & 20 & 36 & 32 & 8 & 4 \\
\hline \multirow{2}{*}{$\begin{array}{l}\text { Signing a } \\
\text { petition }\end{array}$} & Pre-Course & 47.4 & 36.8 & 12.3 & 1.8 & 1.8 \\
\cline { 2 - 7 } & Post-Course & 50 & 40 & 4 & 0 & 4 \\
\hline $\begin{array}{l}\text { Attending a } \\
\text { meeting }\end{array}$ & Pre-Course & 15.8 & 29.8 & 36.8 & 10.5 & 7.0 \\
\cline { 2 - 7 } & Post-Course & 16 & 42 & 32 & 2 & 6 \\
\hline \multirow{2}{*}{$\begin{array}{l}\text { Volunteering } \\
\text { Attend an event } \\
\text { (rally, march, } \\
\text { trip, festival) }\end{array}$} & Pre-Course & 29.8 & 40.4 & 22.8 & 5.3 & 1.8 \\
\cline { 2 - 7 } & Post-Course & 32 & 44 & 14 & 6 & 2 \\
\cline { 2 - 7 } $\begin{array}{l}\text { Participate in } \\
\text { non-violent } \\
\text { direction action } \\
\text { (sit-in) }\end{array}$ & Post-Course & 30.3 & 38.6 & 24.6 & 7.0 & 1.8 \\
\cline { 2 - 7 } & Pre-Course & 17.5 & 29.8 & 31.6 & 8.8 & 2 \\
\hline $\begin{array}{l}\text { Join (become a } \\
\text { member) }\end{array}$ & Post-Course & 14 & 32 & 35 & 10 & 4 \\
\cline { 2 - 7 } & Post-Course & 34 & 24 & 30 & 8 & 4.8 \\
\hline
\end{tabular}


Most of the frequencies were approximately the same from the pre-course survey to the post-course survey. It may be interesting to note that the percent increased, from pre-course survey to post-course survey, for students who were likely to conserve water (11.1\%), reduce consumption (8.9\%), and buy used or recycled products $(8.4 \%)$. The frequencies do not seem to show any large changes in the response percentages for students' likeliness of getting involved with an environmental organization. It is worth noting that vast the majority ( $90 \%$ ) of students are likely or very likely to get involved by signing a petition, which may be because it is way they can help without using much time or resources. 


\section{DISCUSSION}

The purpose of this chapter is to explain the data results for the knowledge retention study and the personal opinion survey study. Factors that may have affected the results are explained as well. This chapter reflects on the main findings in this thesis. Section A returns to the discussion of environmental knowledge retention as a result of subjects taught through indoor lectures and lessons taught in outdoor, place-based lessons. Section B discusses the results of the personal opinion study in terms of correlations between knowledge and activism, student learning styles, outdoor activity preferences, and course effectiveness.

\section{A. Knowledge Retention Study}

The quiz results were not found to be statistically significant for location, whether they were taken after the course lecture or after the field trip, but the mean was still slightly smaller for quizzes taken post-lecture than for quizzes taken post-field trip. It is possible that this may have shown significance with a larger sample size. It is possible that some students may not have put forth their best effort on the quizzes, since the quiz scores did not affect their course grade. Another limiting factor, which may have caused the small difference in means, could have been that the quizzes were taken at the end of a class session, when students might have been tired or anxious to leave.

Quiz results did show that student quiz scores for the topic Bill Baggs State Park was significantly higher than the three other topics in the $4 \times 2$ ANOVA. This main effect indicated that the student's quiz scores tended to be higher for the Bill Baggs State Park field trip than for the other trips, but this was not the focus of this study. Results also 
showed that quiz scores for Florida Keys National Marine Sanctuary were significantly higher than those from the Jonathan Dickinson State Park topic.

Some factors, confounding variables, that may have affected the differences between quiz topics may be that there were three different teaching assistants, or lab instructors, for the six sections assigned to this study. Each instructor may have a different teaching style, pace, and coverage of material. As indicated in the survey responses, students enjoyed the field trips (56\% strongly agree and $40 \%$ agree), but they might have enjoyed some trips more than others. The different instructor techniques could have had an impact on the students' enjoyment level. Another issue may be that the tests were not of the same difficulty level, although they were designed to be. Students may also have learned some of the information from the corresponding lecture course, EVR 3013, or other environmental classes, which may have added to their knowledge of some subjects over others.

The environment itself might have played a role in the quiz scores. Students are accustomed to taking quizzes in quiet classrooms, so taking them outside could have had an impact on their concentration, excitement level, comfort and familiarity, knowledge recall, or a number of other things that could affect concentration during quizzes, and in turn their scores. It was noted that students could have not performed well on the quizzes because they seemed tired and anxious to go home after the three-hour field trip. Enjoying the trip more could have led to the students paying better attention to information on the trips and in turn scoring higher on the quizzes. Since experiential learning techniques involve a time for the learner to reflect on the experience to gain full understanding of the information, students may have scored higher on quizzes if they 
were given more time to reflect on their experience before taking it (Jacobson, 2006; Gair, 1997; Rillo, 1985). Aggregate learning, prior knowledge from other topics and even quiz format, may have led to increased quiz scores since the last two quizzes were the ones that were significantly higher.

\section{B. Personal Opinion Study}

This section discusses the results of the survey portion of the study. Possible factors that affect the results are also discussed as well as any problems with the collection and analysis.

\section{Mean scores of reliability scales}

The mean knowledge score increased from the pre-course survey to the postcourse survey, which means that the students felt their knowledge of environmental issues improved since taking the course. The score also increased for students' willingness to participate in environmental activism. The activism score combined how willing students were to participate in personal conservation efforts, such as recycling, choosing sustainable transportation, adopting a sustainable diet, etc. (Table 11, page 36), and willingness to get involved with an environmental organization (Table 12, page 36). The fact that each of these categories showed increase implies that the course had a positive effect on the students' interest in taking action to improve environmental problems. Statistical significance was found through a Pearson's Correlation of these question sets, led to the conclusion that before the course, students' assumed environmental knowledge had no relationship to their personal conservation efforts or environmental organization involvement, but that after the course their environmental 
knowledge did have a relationship with their personal conservation efforts and overall environmental activism.

\section{Correlations}

The Pearson's Correlation indicated that as students' assumed knowledge increased so did their interest in overall activism and conservation efforts after taking the course. The correlation can be associated with the four levels of environmental literacy by increasing their understanding of ecological processes, humans' role in nature, and how they fit into the concepts (Rillo, 1985). Students' increased knowledge and activism increased because the course included outdoor education, where students are able to experience the subjects they are learning about, giving a better understanding and an emotional connection to the subject. Through environmental education, students not only gain environmental stewardship, but they can improve their own self-discipline, focus, cognition, and health (EPA, 2005).

\section{Learning styles}

Active learning was the learning type with the highest response percentage, reaffirming the idea that the quizzes used may not have been the best way to record knowledge retention. It is interesting to note that while many students chose active learning as their preferred method of learning, the quiz scores after the active learning experience was not statistically significantly higher. The quiz questions themselves can be a good indicator of knowledge retention, but the variety of factors affecting students' ability to perform well had a major effect on quiz scores. If a similar study is conducted in the future, it is recommended to try and control for those factors. Recommendations for doing so are discussed in the next chapter. 
Students' responses to learning style preference were not expected to change significantly from the pre-course survey to the post-course survey. However, there was a large increase from 17.5 to 30 percent (Table 6, page 32) in the students who chose listening as their preferred learning method. Since the survey data could not be statistically analyzed without matching each student's pre and post surveys, only the percentages can be compared. The students who chose reading as their preferred learning method decreased from 24.6 to 12 percent (Table 7, page 32). The responses may have changed because the students generalized their answers on the pre-course survey to previous learning experiences, whereas the post-course response may have been more skewed toward their experience in this course.

\section{Outdoor Activities}

Students overall responses showed that they enjoyed outdoor activities more after taking the course. One of the activities involved in the course, "nature/wildlife watching" decreased by about $5 \%$, which may be because it is rare on these trips to see wildlife. It was a common complaint from students throughout the course that they did not see many animals because the large groups of students scared them away, and that may have affected their interest in the activity. Students' post-course survey responses also showed that they were more likely to engage in more outdoor activities in the future and $74 \%$ of students said the course had a positive influence on their interest in participating in outdoor activities. This increase in their desire to partake in outdoor activities most likely occurred because humans do benefit from time spent in nature and their appreciation increases such as Richard Louve depicts. Our mental, physical and spiritual health depend human connection with nature, which has become rare (Louve, 2005). In turn, the 
more humans seem to learn about and interact with nature, the more they are given the opportunity to understand it and form personal connections with it and through these connections an "ecological conscience" can be developed (Smith, 1972).

\section{Course Effectiveness}

Results from students' preferred learning styles were compared with how effective they thought the class was (effectiveness score). Although the scores only vary slightly, students who preferred active or experiential learning methods found the class to be slightly more effective. There is probably not a major difference in means because outdoor education, although great for active (kinesthetic) learners, includes a variety of learning styles that can be a helpful learning tool for auditory and visual learners as well (Ladue, 2002). The course also included a research project, which may have added to students' connection by being able to choose a specific ecology topic that interested them to increase their understanding.

It is not surprising to find that more students strongly agreed to have gained more understanding of and connection to nature from the course, because gaining true environmental literacy is a time intensive process. For many students this may have peaked their interest and understanding of environmental issues and their connection with nature, but there is no sure way of knowing how many more personal experiences it may take for one to achieve what Kevin Coyle deems "True Environmental Literacy" (EPA, 1990). There is no way of knowing how long the reflective/processing phase of after an active learning experience can take, it would vary for each individual student.

Environmental education, specifically ecological education, has a pivotal part in the complex process of expanding environmental literacy. A good indication of this 
within the study were the high response levels of students who were concerned about environmental issues and feel the need to act on them combined with the even higher agreement responses of students' increased connection with nature because of the course. The difference in response levels of concern and connection is because of the time it can take for a person to move through the steps of becoming environmentally literate (EPA, 1990). In addition, the fact that $96 \%$ of students responses were "agree" or "strongly agree" that the field trips contributed to their understanding of the course material is a good indicator that outdoor, place-based, experiential education plays a major role in the process of connecting environmental responsibilities to nature by experiencing part of it (Smith, 1972).

These results all seem to correspond well with similar studies, and point to experiential, especially outdoor, education as a very effective environmental education method. In a 2009 study involving the same course, the research project showed very similar results, that active engagement of students using experiential, place-based learning can enhance knowledge retention as well as change environmental attitudes (Matthews, 2009). 


\section{CONCLUSION}

The purpose of this chapter is to wrap-up the thesis and look towards the future. It begins by providing a brief summary of the research results. It also offers suggestions for future research and provides recommendations for educators and institutions as related to outdoor learning activities. The chapter concludes with some final thoughts regarding the importance of environmental education via outdoor learning activities as a means to help individuals reaffirm their relationship with nature.

\section{A. Summary of Research Results}

Although this study did not show statistical significance between quiz scores taken after the field trips and after the class-lectures, it did show that mean quiz scores taken after the field trips $(\mathrm{M}=3.56, \mathrm{SD}=1.06)$ were slightly higher than those taken after the class lecture $(\mathrm{M}=3.46, \mathrm{SD}=1.09)$. In addition, student opinion surveys did support the idea that experiential, outdoor education had a positive influence on their understanding of and connection to nature (specifically south Florida ecosystems).

The quizzes, as discussed earlier, also need more work, since there are many outside factors that come into account in the different locations they are taken in that could affect their concentration while taking the quizzes. This study is worth another look, the method of studying knowledge retention must be altered to try and control for outside factors affecting the quiz scores and the sample size should be much larger.

Students' survey responses showed that field trips had a positive impact on their understanding of the information as well. In addition, the survey responses illustrated that the course help increase students' concern for environmental issues and need to take 
action to solve environmental problems. The surveys gave very pertinent insight into student opinions about the course's effectiveness, but should have had identifiers for pairing each student's pre-course survey with post-course survey. Students were more likely to participate in outdoor activities after taking the course, and the sizeable change may indicate that they felt more connected just from one summer semester course. If the students actually do participate in more outdoor activities, their understanding of and connection with nature have the potential to increase even more over time, deepening their ecological literacy level.

\section{B. Suggestions for Future Research}

There are a few concerns and alterations that should be taken into account should this study be replicated. These include changes related to the sample size, use of control groups, the use of identifiers and the methodology of the quizzes themselves. The study should, above all, have a larger sample size. A larger sample size may show statistical significance and will definitely give a more robust result. Adding a control group is also suggested to show differences between students who took the course and those who did not. This could be students from other core curriculum science classes and/or could be from a different subject matter all together. It may also be useful to gather data from a similar course at a different university.

If quizzes are to be used as the method for collecting knowledge retention of the subject material, then some changes should be made. There should be more questions in the quiz to increase variability of quiz scores within the class and give the students more of an opportunity to display their understanding of the course material. Reflection time, 
an essential part of experiential learning, should be taken into account. This may be done by giving students time to reflect on the information, but could also be an additional study factor and only given to half of the students.

Students may need a more comfortable environment to take the quiz when on the field trips, since they are used to indoor test taking or this could be tested as well by giving some students the quizzes indoors and some outdoors. Either way, the quizzes should be taken in the same type of environment to control for the impact on a students' comfort level and concentration. Surveys and quizzes should all have identifiers so that they can be linked to the student who took them and the data from each can be tested for statistical significance between one another. Student identification numbers could be used so that the instructor grading the paper does not have bias by seeing a students' name and so that the students will not have to remember another number.

A longer, more in depth survey would give deeper understanding into the students' personal opinions. By conducting the study over the course of a few semesters, at least a year, there would be more participants to increase the sample size and it would show if any variability exists between the data from students who take the course in the fall, spring, or summer semesters.

It may also be of interest to future researchers to record students' declared majors and prior experience with the subject material to see if that has an effect on their quiz scores and survey responses. In order to gain a deeper understanding of the students' appreciation there could me more complex questions about connection with and appreciation for nature and interviews (random or selected based on extreme responses). It also may be beneficial to use the Nature Relatedness (NR) scores used in a previous 
study to further analyze the relationship between connections and how they relate to knowledge of the subject and interest in activism.

\section{Recommendations for Educators and Institutions}

The results from this study lead to a number of recommendations for both educators and academic institutions. These include course, curriculum, and institutional changes to promote environmental education and outdoor learning activities. In the future, it may be beneficial for the Ecology of South Florida lab to include each student's personal interests into their course involvement in order to increase their personal connection and understanding of their relationship with nature. This can be done through some kind of personal project such as a creative project, carbon footprint, home audit, research project, volunteer work, etc. It may be important for the instructor or the student to take the student's preferred learning style into account before choosing a personal connection assignment. It is additionally important that sustainability and deep ecology topics are covered during the course.

Integrating technology into the coursework could also be a beneficial tool to increase understanding and connection, since most people use technology everyday, such as Project Noah, a GPS species identification tool (Networked Organisms, 2012). Requiring all undergraduate students at Florida International University, or all universities for that matter, to participate in an environmental education activity such as a course before graduation would help to ensure that the main goal of environmental education is met, increasing public knowledge of ecological relationships to include humans in order to improve conservation (Smith, 1972). An environmental education 
course may involve outdoor education, sustainability, deep ecology, or a colloquium (such as the course requirement at Florida Gulf Coast University).

It may also be helpful to students if the outdoors/nature is included in nonenvironmental courses as a learning tool, as outdoor education includes any subject matter that could best be learned outside the classroom (Rillo, 1985). A final recommendation is to ensure preservation of the Florida International University Nature Preserve, or any natural space at a school or university. Preserving these spaces will set an example for students that preserving natural spaces is important and that natural lands are not expendable (Orr, 1994). Keeping these areas on campus also gives a local, easily accessible location for natural experiences, outdoor education, and increase connection with and understanding of nature, thus increasing environmental literacy.

\section{Final Thoughts}

The current environmental crisis offers many challenges as to how to deal with environmental degradation, however many people still do not see themselves as a factor in those problems. Environmental education is essential in bridging the gap between humans and nature, curing nature deficit disorder, and as a reminder that people are part of the planet. Teaching facts about the problems and listing solutions are helpful, but people do not care about something unless they know about it and the deeper the understanding becomes, the more connected to an issue one feels.

As Stephen Jay Gould said, "We cannot win this battle to save species and environments without forging an emotional bond between ourselves and nature as well for we will not fight to save what we do not love" (Orr, 1994). However, this is not the 
practice behind most environmental education programs. Environmental educators should find this study compliments prior findings about experiential, environmental, and outdoor education and take the results from this study into account when planning lessons in order to help their student get the maximum understanding from the course material being covered.

Experiences in nature are an essential aspect in order to grow a connection with nature, and that connection is essential for increasing the understanding and environmental literacy needed to help solve our current environmental crisis. This is not to say that outdoor experiences are the only important aspect in environmental literacy gains. It is also important the students understand their connection with the environment and for some that may come in the form of personal reflection such as a carbon footprint assignment or a personal research project. It is essential that a bond with nature and an understanding one's connection with nature develop for people to feel the need to take action to protect the environment and solve the current environmental crisis. 


\section{REFERENCES}

American Forest Foundation. (2012). Why EE is important. Retrieved from http://www.plt.org/why-ee-is-important

American Institutes for Research. (2005). Effects of outdoor education programs for children in California. Retrieved from http://www.sierraclub.org/youth/california/outdoorschool_finalreport.pdf

Boss, J. A. (1999). Outdoor education and the development of civic responsibility. ERIC Digest. Retrieved from http://noiorizonturi.ro/attachments/article/44/Outdoor\%20Education $\% 20$ and $\% 20$ the $\% 20 \mathrm{De}$ velopment $\% 20$ of\%20Civic\%20Responsibility.pdf

Chawla, L. "Learning to love the natural world enough to protect it. Barn, Volume 2012(2). Retrieved from http://www.ntnu.edu/noseb/research/barn

Cheng, J. C. H., \& Monroe, M. C. (2010). Connection to nature: Children's affective attitude toward nature. Environment and Behavior, Vol.44(1). Retrieved from http://eab.sagepub.com.ezproxy.fiu.edu/content/44/1/31

Dewey, J. (1998). Experience and Education: $60^{\text {th }}$ anniversary edition. West Lafayette, IN: Kappa Delta Pi.

Duerden, M. D., \& Witt, P. A. (2010). The impact of direct and indirect experiences on the development of environmental knowledge, attitudes, and behavior. Journal of Environmental Psychology, Volume 30(4). Retrieved from http://www.sciencedirect.com.ezproxy.fiu.edu/science/article/pii/S027249441000 0344

Environmental Protection Agency (EPA). (1999). National environmental education act (NEEA) of 1990. Retrieved from http://www.epa.gov/education/neea.html

Faber Taylor, A., \& Kuo, F. E. (2008). Children with attention deficits concentrate better after walk in the park. Journal Of Attention Disorders, Vol.12(5). Retrieved from http://jad.sagepub.com.ezproxy.fiu.edu/content/12/5/402

Faber Taylor, A., \& Kuo, F. E. M. (2011). Could exposure to everyday green spaces help treat ADHD? Evidence from children's play settings. Applied Psychology: Health and Well Being, Vol.3(3). Retrieved from http://onlinelibrary.wiley.com.ezproxy.fiu.edu/doi/10.1111/j.17580854.2011.01052.x/full 
Gabrielsen, M. A. \& Holtzer, C. (1965). The role of outdoor education. New York: Center for Applied Research in Education.

Gair, N. P. (1997). Outdoor education: theory and practice. London: Cassell.

Gibson, P. (2010). Step Outside For Learning. Green Teacher, Issue 91, p18-21.

Hammerman, D. R., and William M. Hammerman. (1973). Outdoor education; a book of readings. Minneapolis: Burgess Pub.

Howden, E. (2012). Outdoor experiential education: learning through the body. New Directions for Adult and Continuing Education, Volume 2012(134). Retrieved from

http://onlinelibrary.wiley.com.ezproxy.fiu.edu/store/10.1002/ace.20015/asset/200

15 ftp.pdf? $\mathrm{v}=1 \& \mathrm{t}=\mathrm{h} 85 \mathrm{gko} 02 \& \mathrm{~s}=62747 \mathrm{a} 93507 \mathrm{~d} 80 \mathrm{ae} 2195 \mathrm{fc} 6 \mathrm{c} 5 \mathrm{e} 88 \mathrm{c} 9 \mathrm{a} 4 \mathrm{be} 20317 \mathrm{~d}$

Jones, J. (2011). Americans increasingly prioritize economy over environment. Retrieved from http:/www.gallup.com/poll/146681/americans-increasingly-prioritizeeconomy-environment.aspx

Jurin, R.R. \& Fortner, R.W. 2002. Symbolic beliefs as barriers to responsible environmental behavior. Environmental Education Research, Volume 8(4), p.37394.

Klein, C. \& Plankis, B. (2010). The corals connection: building personal connections to environmental issues. The Science Teacher, Volume 77(2). Retrieved from http://go.galegroup.com.ezproxy.fiu.edu/ps/retrieve.do?sgHitCountType=None\&s ort $=\mathrm{DA}$ -

SORT\&inPS $=$ true \&prodId $=$ AIM\&userGroupName $=$ flstuniv $\&$ tabID $=$ T002\&searc $\mathrm{hId}=\mathrm{R} 1 \&$ resultListType $=$ RESULT_LIST\&contentSegment $=\&$ searchType $=$ Adva ncedSearchForm\&currentPosition=1\&contentSet=GALE\%7CA218950535\&\&do cId=GALE $\mid$ A218950535\&doc Type $=$ GALE\&role $=\&$ docLevel=FULLTEXT

Kolb, D. A. (1984). Experiential learning: experience as the source of learning and development. Englewood Cliffs, NJ: Prentice Hall. Retrieved from http://www.learningfromexperience.com/images/uploads/process-of-experientiallearning.pdf 
Kortenkamp, K. \& Moore, C. F. (2000). Ecocentrism and anthropocentrism: Moral reasoning about ecological commons dilemmas. Journal of Environmental Pyschology, Volume 21. Retrieved from http://psych.wisc.edu/moore/PDFsMyPapers/Kortenkamp\&Moore2001.pdf

Lawrence, E. K. 2012). Visitation to natural areas on campus and its relation to place identity and environmentally responsible behaviors. Journal of Environmental Education, Volume 43(2), p93-106.

Louv, R. (2005). Last child in the woods: saving our children from nature-deficit disorder. Chapel Hill, NC: Algonquin of Chapel Hill.

Matthews, M. (2009) Assessing effectiveness of pedagogical techniques used in environmental education: content acquisition and attitude shifts in an experiment with pine rocklands in the ecology of south Florida laboratory. (Masters Thesis). Florida International University, Miami, FL.

Müller, M., Kals, E., \& Pansa, R. (2009). Adolescents' emotional affinity toward nature: A cross- sectional study. Journal of Developmental Processes, Volume 4(1). Retrieved from http://www .psych.utah.edu/people/people/fogel/jdp/journals/6/journal06-06.pdf

Murphy, S. A., Nisbet, E. K., \& Zelenski, J. M. (2009). Linking Individuals' Connection With Nature to Environmental Concern and Behavior. Environment and Behavior, Volume 41(5). Retrieved from http://eab.sagepub.com hosted at http://online.sagepub.com

Neill, J. (2005). John Dewey: Philosophy of Education. Retrieved from http://wilderdom.com/experiential/JohnDeweyPhilosophyEducation.html

Networked Organisms. (2012). Project Noah. Retrieved from http://www.projectnoah.org/

Nadelson, L. S. \& Jordan, R. J. (2012).Student attitudes toward and recall of outside day: An environmental science field trip. Journal of Educational Research, Vol.105(3), 220-231.

Naess, A. (1973). The shallow and the deep. Inquiry, Volume 16. Retrieved from http://www.ecology.ethz.ch/education/Readings_stuff/Naess_1973.pdf 
The Nature Conservancy. (2011). Connecting America's youth to nature. $C \& N N$ Research, volume 5. Retrieved from http://www.nature.org/newsfeatures/kids-innature/kids-in-nature-poll.xml

National Environmental Education \& Training Foundation (NEETF). (1999). NEEFT/Roper Report Card. Washington, D.C.: National Environmental Education \& Training Foundation. Retrieved from http://www.neefusa.org/pdf/roper/99reportcard.pdf

The National Environmental Education and Training Foundation (NEETF). (2005).

Environmental literacy in America: what ten years of NEETF/Roper research and related studies say about environmental literacy in the U.S. Publication. Retrieved from http://www.neefusa.org/pdf/ELR2005.pdf

National Environmental Education Advisory Council (NEEAC). (2005). Setting the standard, measuring results, celebrating successes: a report to congress on the status of environmental education in the United States. Retrieved from http://epa.gov/enviroed/pdf/reporttocongress2005.pdf

Newport, F. (2010). Americans' global warming concerns continue to drop. Gallup. Retrieved from http:/www.gallup.com/poll/126560/americans-global-warmingconcerns-continue-drop.aspx

Orr, D. W. (1992). Ecological literacy: education and the transition to a postmodern world. Albany, NY: State University of New York Press.

Orr, D. W. (1994). Earth in mind: on education, environment, and the human prospect. Washington, DC; Covelo, CA: Island Press.

Orr, D. W. (2004). Earth in Mind. Washington (DC): Island.

Rillo, T. J. (1985). Outdoor education: beyond the classroom walls. Bloomington, IN: Phi Delta Kappa Educational Foundation.

Roth, C. E. (1992). Environmental literacy: Its roots, evolution, and directions in the 1990s. Columbus, OH: ERIC/CSMEE.

Scholz, R. W. (2011). Environmental literacy in science and society. Cambridge, UK: Cambridge University Press. 
Schultz, P. W. (2000). Empathizing with nature: The effects of perspective taking on concern for environmental issues. Journal of Social Issues, Vol. 56(3). Retrieved from http://www.stanford.edu/ kcarmel/CC_BehavChange_Course/readings/Additiona l\%20Resources/J\%20Soc\%20Issues\%202000/schultz_2000_3_empathy_a.pdf

Smith, A. S. \& Williams, D. R. (1999). Ecological education in action: on weaving education, culture, and the environment. Albany, NY: State University of New York Press.

Smith, J. W. (1972). Outdoor education. Englewood Cliffs, NJ: Prentice-Hall.

United Nations Educational, Scientific \& Cultural Organization (UNESCO). (1975). The Belgrade charter. Nature Study, Volume 29 (3\&4), p.6-7.

Wells, N.M. (2000). At home with nature: Effects of 'greenness' on children's cognitive functioning. Environment and Behavior. Vol. 32, No. 6. Retrieved from http://www.evergreen.ca/en/resources/schools/research-policy.sn

Wilson, E. O. (1984) Biophilia. Cambridge, MA: Harvard UP.

Wray-Lake, L., Flanagan, C. A., \& Osgood, D. W. (2009). Examining trends in adolescent environmental attitudes, beliefs, and behaviors across three decades. Environment and Behavior, Volume 42(1). Retrieved from http://eab.sagepub.com.ezproxy.fiu.edu/content/42/1/61.full.pdf 
Appendix 1- Quizzes used in the Knowledge Retention Study 


\section{$\underline{\text { Everglades National Park Quiz }}$}

1. The "base of the everglades" is
a. Sawgrass
b. Alligator
c. Periphyton
d. Pickerelweed

2. This $\%$ of pine rockland remains in Miami-Dade county
a. $2 \%$
b. $4 \%$
c. $10 \%$
d. $20 \%$

3. Sawgrass is a
a. Grass
b. Rush
c. Hedge
d. Sedge

4. Describe the relationship between pine rockland and hardwood hammock.

5. Name two plant species that dominate the pine rockland ecosystem. 


\section{Jonathan Dickinson State Park Quiz}

1. Name \& describe the soil in the scrub ecosystem (give two characteristics).

2. Define xerophyte.

3. Describe the floral competition (or draw the diagram) in the scrub ecosystem.

4. This keystone species found in the scrub habitat creates burrows, which other species live in, and is common throughout central Florida, Georgia, Alabama, and Louisiana.
a. Burrowing Tortoise
b. Burrowing Mouse
c. Gopher Tortoise
d. Gopher Mouse

5. This is the most extensive terrestrial ecosystem in Florida.
a. Sand Pine Scrub
b. Tree Islands
c. Pine Rockland
d. Pine Flatwood 


\section{Florida Keys National Marine Sanctuary Quiz}

1. What is coral?
a. A plant
b. An animal
c. A fungus
d. An algae

2. What type of relationship best describes the interaction between individual corals and zooxanthellae?
a. Commensalism
b. Parasitic
c. Mutualism
d. Ammensalism

3. Define zooxanthellae \& explain what happens to it when coral bleaches.

4. Describe two anthropogenic threats to coral reefs. (not bleaching)

1.

2.

5. Coral can reproduce sexually by spawning and reproduce asexually by budding (breaking off) and starting a new colony.

a. True

b. False 


\section{Bill Baggs State Park Quiz}

1. Maritime hammocks:
a. Have nutrient rich soils
b. Develop on coastal dune systems
c. Are inland due to salt intolerance
d. Have a tall growth height

2. Which is not a type of mangrove found in South Florida?
a. Red
b. Blue
c. White
d. Black

3. Seagrasses:
a. Have adapted to live in a saline environment
b. Can not grow completely submerged
c. Distribute their pollen by crustaceans
d. Are not a source of food for sea creatures.

4. The soil in the scrub ecosystem is

5. Name two anthropogenic effects to seagrass beds

a.

b. 
Appendix 2- Personal Opinion Surveys 


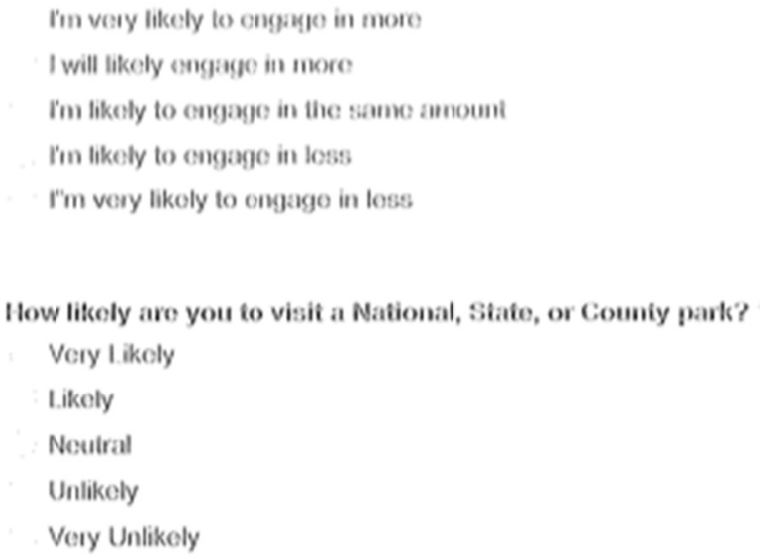

How likely are you to paricipate in the following conservation efforis

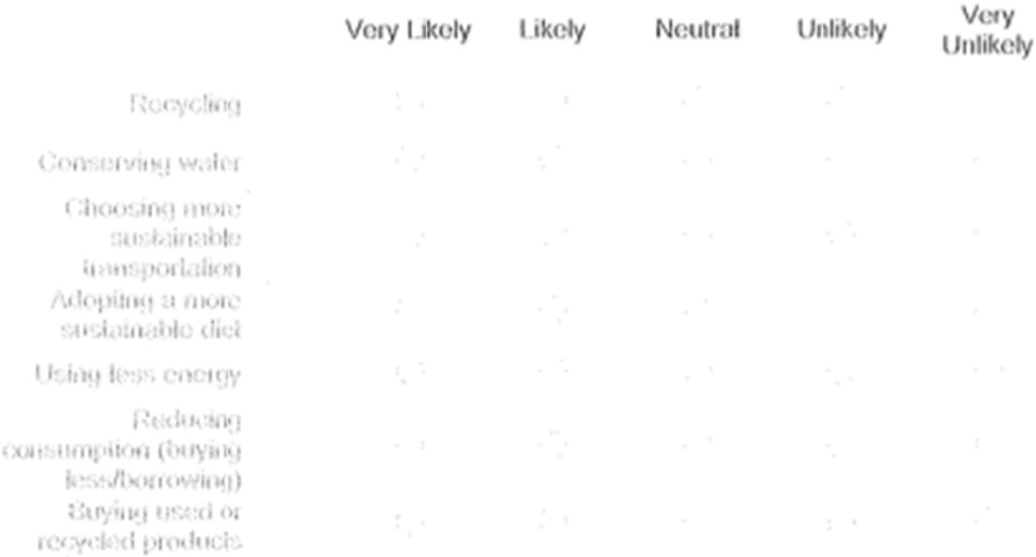

How likely are you to get involved with an environmental organization by....

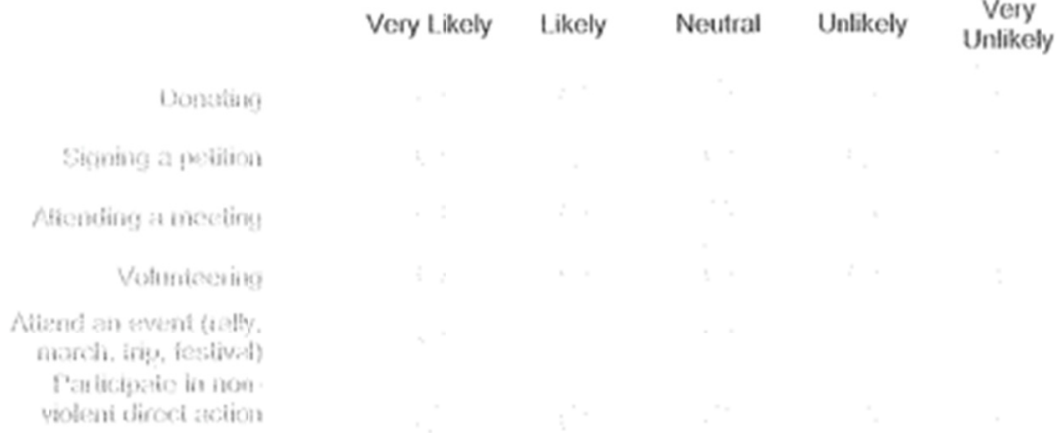




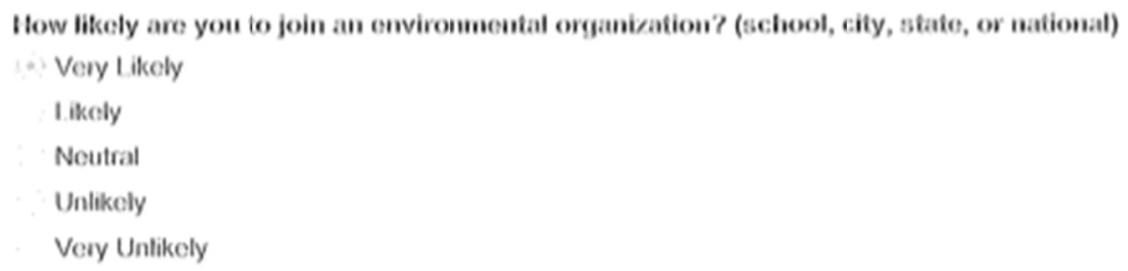

How much do you know about each of the following:

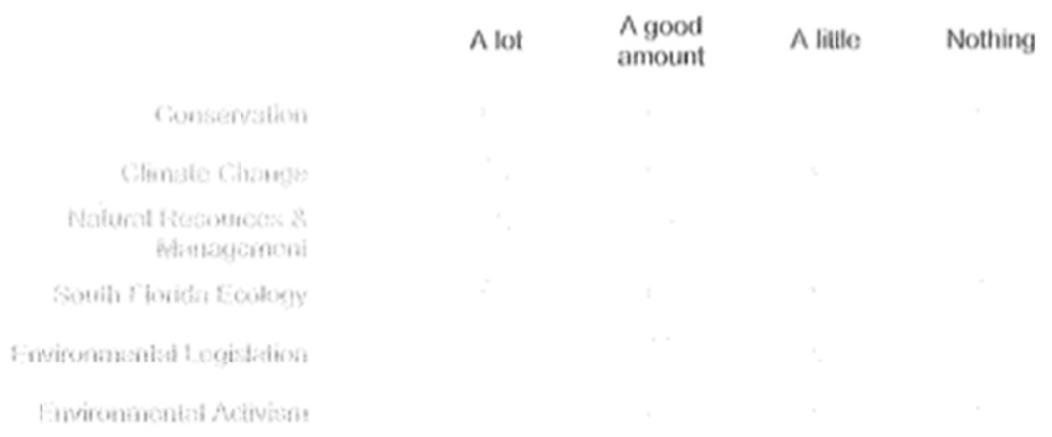

I learn a subject best when

I listen to information about it

I watch a video or demonstration of it

I read about it

I write something on it

I participate in an activity involving it

Other:

Choose your preferred method of learning about science or ecology

In class lectures

in class videos

Self-guided study (reading, research)

Ficld trips

Other:

Submit 


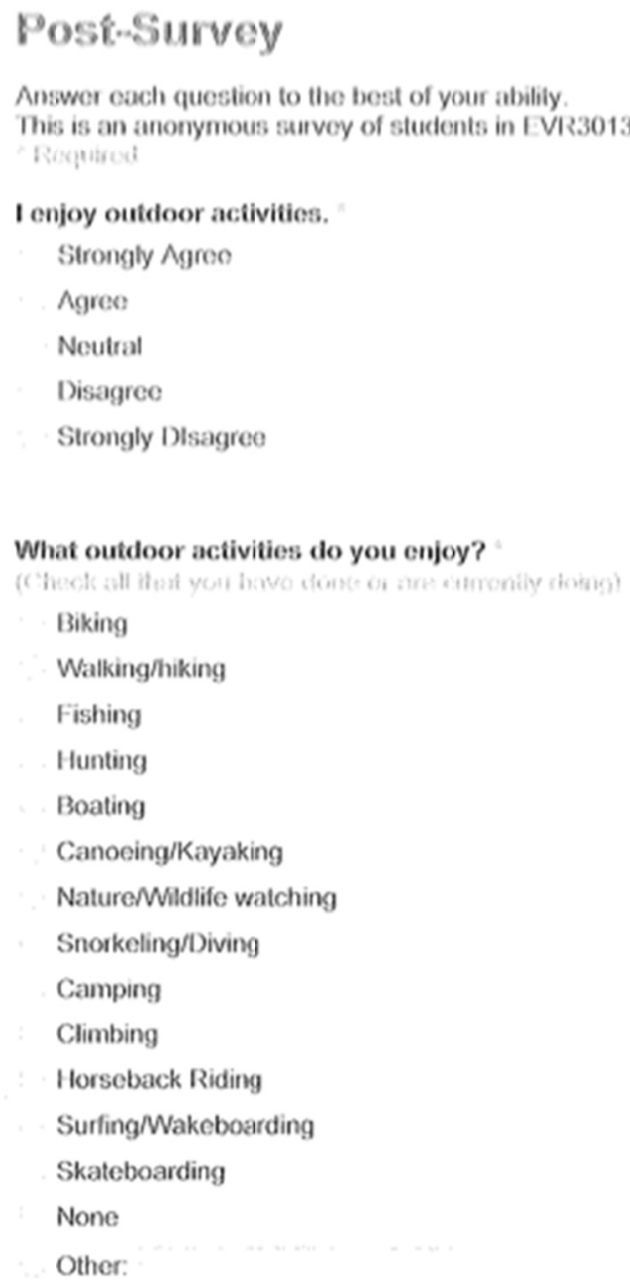

Do you belong to any organizations that do outdoor activities?

Yes

No

If YES, what organization do you belong to?

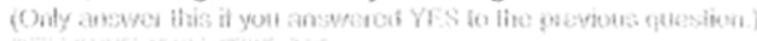

How likely are you to change the amount of outdoor activities you engage in in the future? 
Im vory likely to ongrage in more

I will likely engage in more

I'm likely to engage in the same amouni

I'm tikely to ongago in los:

I"m very likely to engage in loss

Did taking this class influence the amount ouicloor activities you will do?

Yes, Positive Inlluenco

Yes, Negative Influence

No

Unsure

How likely are you to visit a National, State, or County park?

Very likely

likely

Neutral

Unlikely

Very Unlikely

How likely are you to participate in the following conservation efforts

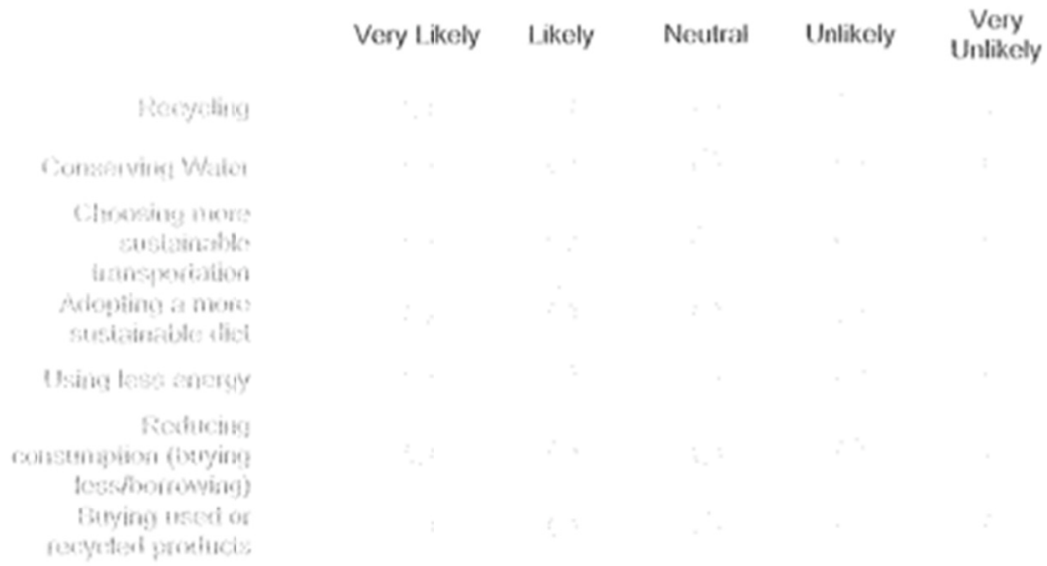

Hov likely are you to get involved with an environmental organization by....

Very Likely Likely Neutral Unlikely Unlikely

Ixwisting 


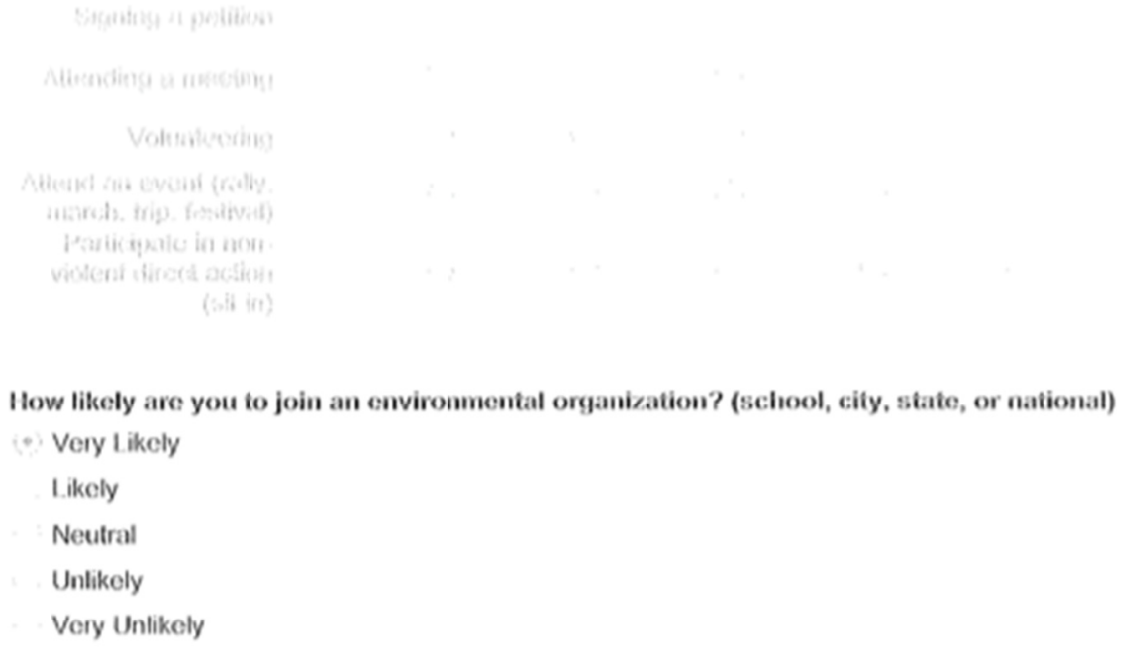

Hove much do you know about each of the following:

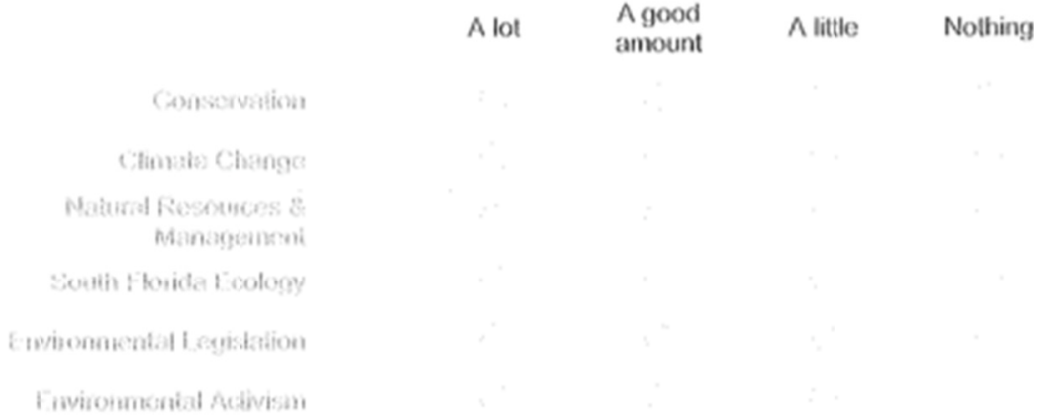


In class activitios:

Sell -guiked study (reading, rosesurch)

Fiokl Trips:

Ollos:

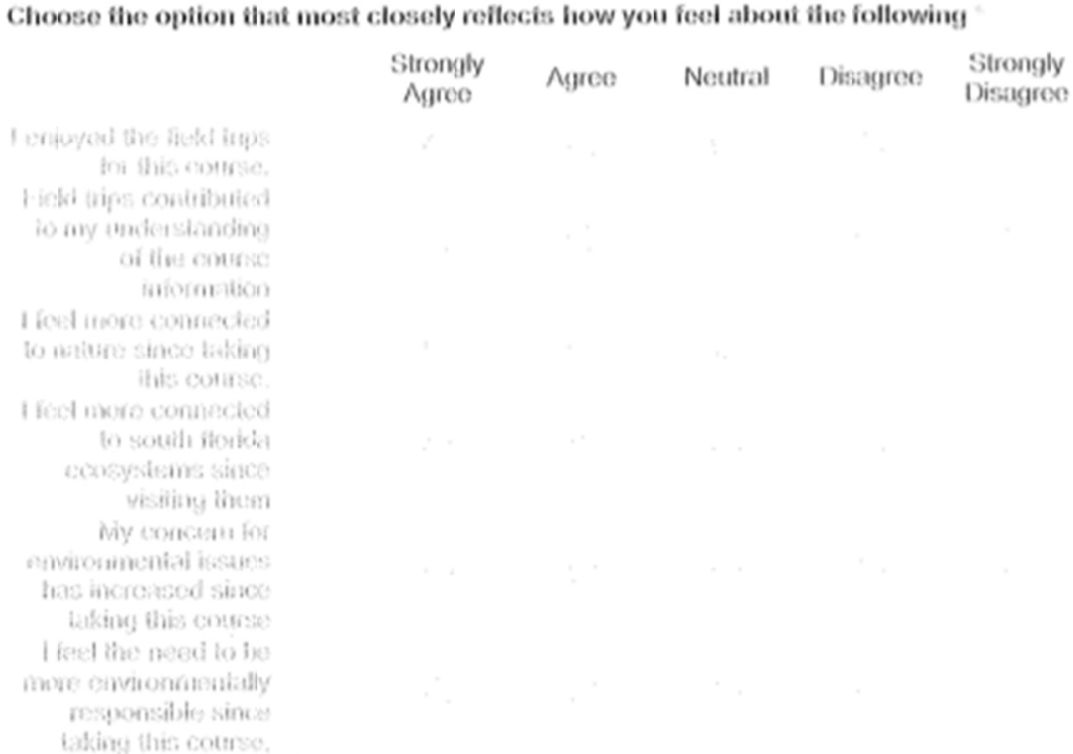

What current environmental activities or groups are you involved in?

What did you enjoy most about this course? 
What would you have changed about this course?

Other Comments:

Submit

Powened in (ionole froc:

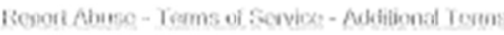

